Article

\title{
Impact of Radar Reflectivity and Lightning Data Assimilation on the Rainfall Forecast and Predictability of a Summer Convective Thunderstorm in Southern Italy
}

\author{
Stefano Federico ${ }^{1} \mathbb{D}$, Rosa Claudia Torcasio ${ }^{1, * \mathbb{D}}$, Silvia Puca ${ }^{2}$, Gianfranco Vulpiani ${ }^{2}$, Albert Comellas Prat ${ }^{3}$, \\ Stefano Dietrich ${ }^{1}$ (D) and Elenio Avolio ${ }^{4}$ (D) \\ 1 National Research Council of Italy, Institute of Atmospheric Sciences and Climate (CNR-ISAC), \\ Via del Fosso del Cavaliere 100, 00133 Rome, Italy; s.federico@isac.cnr.it (S.F.); s.dietrich@isac.cnr.it (S.D.) \\ 2 Dipartimento Protezione Civile Nazionale, 00189 Rome, Italy; silvia.puca@protezionecivile.it (S.P.); \\ gianfranco.vulpiani@protezionecivile.it (G.V.) \\ 3 National Research Council of Italy, Institute of Atmospheric Sciences and Climate (CNR-ISAC), \\ Strada Pro.Le Lecce-Monteroni, 73100 Lecce, Italy; a.comellas@le.isac.cnr.it \\ 4 National Research Council of Italy, Institute of Atmospheric Sciences and Climate (CNR-ISAC), \\ Zona Industriale ex SIR, 88046 Lamezia Terme, Italy; e.avolio@isac.cnr.it \\ * Correspondence: rc.torcasio@isac.cnr.it
}

\section{check for} updates

Citation: Federico, S.; Torcasio, R.C.; Puca, S.; Vulpiani, G.; Comellas Prat, A.; Dietrich, S.; Avolio, E. Impact of Radar Reflectivity and Lightning Data Assimilation on the Rainfall Forecast and Predictability of a Summer Convective Thunderstorm in Southern Italy. Atmosphere 2021, 12, 958. https://doi.org/10.3390/ atmos12080958

Academic Editor: Lawrence D. Carey

Received: 18 June 2021

Accepted: 22 July 2021

Published: 26 July 2021

Publisher's Note: MDPI stays neutral with regard to jurisdictional claims in published maps and institutional affiliations.

Copyright: (c) 2021 by the authors. Licensee MDPI, Basel, Switzerland. This article is an open access article distributed under the terms and conditions of the Creative Commons Attribution (CC BY) license (https:// creativecommons.org/licenses/by/ $4.0 /)$.

\begin{abstract}
Heavy and localized summer events are very hard to predict and, at the same time, potentially dangerous for people and properties. This paper focuses on an event occurred on $15 \mathrm{July}$ 2020 in Palermo, the largest city of Sicily, causing about $120 \mathrm{~mm}$ of rainfall in $3 \mathrm{~h}$. The aim is to investigate the event predictability and a potential way to improve the precipitation forecast. To reach this aim, lightning (LDA) and radar reflectivity data assimilation (RDA) was applied. LDA was able to trigger deep convection over Palermo, with high precision, whereas the RDA had a key role in the prediction of the amount of rainfall. The simultaneous assimilation of both data sources gave the best results. An alert for a moderate-intense forecast could have been issued one hour and a half before the storm developed over the city, even if predicting only half of the total rainfall. A satisfactory prediction of the amount of rainfall could have been issued at 14:30 UTC, when precipitation was already affecting the city. Although the study is centered on a single event, it highlights the need for rapidly updated forecast cycles with data assimilation at the local scale, for a better prediction of similar events.
\end{abstract}

Keywords: deep convection; lightning data assimilation; radar data assimilation; 3D-Var; precipitation forecast; predictability

\section{Introduction}

Quantitative precipitation forecast (QPF) is an outstanding mission of the forecaster community and represents, especially for convective events, a very difficult task, because of the multitude of temporal/spatial scales involved and the fast evolution and space variability of rainfall [1-3]. The Mediterranean area is often struck by severe weather events [4] which are determined by specific combinations of factors related to three main ingredients: the warm sea, the orography of the basin and the synoptic-scale meteorology. Deep convective events over the Mediterranean develop mainly in fall and winter [4-12], but they can also occur in other seasons. The storms are often associated with mid-latitude cyclonic systems or wave troughs, with or without secondary cyclogenesis, or with deep moist convection development produced by mesoscale convective systems (MCSs) [13-16]; when an MCS is located over the same area for several hours, large amounts of precipitation can accumulate in less than a day $[10,11,17,18]$. In some cases, very intense and localized precipitation falls for a few hours, with peaks of about $100 \mathrm{~mm}$ per hour, causing flash 
floods; these short-lived events especially occur in summer and fall (i.e., [19-21]) often causing casualties.

Although several dangerous events are highly localized in space and time, the impact of the main synoptic patterns associated with these rainfall events [22,23] also needs to be considered, since a large-scale analysis also allows for improving the predictability of rainfall-related phenomena.

The need for a good QPF, even if only in the short-term, therefore appears to be of primary importance, in order to anticipate and mitigate the impact of severe weather. There are several studies focusing on QPF improvement; for example, the hydrological cycle in the Mediterranean Experiment-First Special Observation Period [24,25], which took place in the northwestern Mediterranean in fall 2012, was aimed at studying intense precipitation and at improving its predictive capacity. Along with other factors, the improvement of QPF involves the enhancement of numerical weather prediction (NWP), the accuracy of which depends on the knowledge of the initial conditions that, in turn, can be improved [26,27]. The continuous advancement of NWP and computational resources allowed the achievement of high horizontal resolutions (HRs, $<=3-4 \mathrm{~km}$ in this paper) in operational NWP coupled with HR data assimilation systems [28,29]. Among the different data sources to assimilate in NWPs, lightning and radar have an important impact on the improvement of the QPF performance.

Lightning data assimilation (LDA) has been widely used in the last two decades to improve precipitation forecasts, at the short and mid-range $(0-24 \mathrm{~h})$ because of some important properties of lightning observations: (a) lightning is located precisely in space and time in areas of deep convection (the spatial error of lightning is less than $200 \mathrm{~m}$ for the dataset used in this paper and lightning is detected instantaneously); (b) lightning data are easy to transfer and do not require broadband connections; (c) lightning data are available in almost real time because the time interval between lightning detection and data availability is of the order of a few minutes; (d) lightning can be detected in remote areas beyond the radar coverage or in complex orographic regions, where the availability of other sources of data is scarce. In the last two decades, several methods were proposed to assimilate lightning in cloud-resolving NWP models (horizontal resolution less that $3-5 \mathrm{~km}$ ) and/or using a parameterization of convective precipitation; early and more recent studies using models with convective rainfall parameterization were based on relationships between lightning and the rainfall rate estimated by microwave sensors on board polar-orbiting satellites [30-33]. The rain rate was assimilated in NWP through latent heat nudging. The study of Papadopulos et al. [34] used lightning to locate convection and the water vapor profiles simulated by the NWP model were nudged towards vertical profiles recorded during convective events. Mansell et al. [35] proposed a method to assimilate lightning by triggering the convective precipitation scheme depending on the observation of flashes; the same method was also successfully used by Lagouvardos et al. [36] and by Giannaros et al. [37] for convective storms over Greece. For cloud-resolving models, different methods have also been implemented. Wang et al. [38] and Gan et al. [39] assimilated LDA, adjusting the vertical velocity simulated by NWP based on the relationship between the frequency of lightning and cloud top height and on the relationship between cloud top height and maximum updraft [40,41]. Marchand and Fuelberg [42] used LDA to adjust the thermal field at the lower atmospheric levels to force convection. Fierro et al. [43,44] proposed a method for LDA based on the adjustment of the water vapor field of NWP; this method can also be used in a 3D-Var framework through the assimilation of pseudoprofiles of water vapor $[45,46]$. The application of LDA through the adjustment of water vapor profiles has been applied in different countries (among others [47-50]), showing a positive impact of LDA on the precipitation forecast at a short range. This method was also applied in the Mediterranean context [51-54], showing a notable potential for successful precipitation forecasts of convective events in the short term.

Radar data are among the sources most widely used in data assimilation (DA; $[26,27,55-60]$ ) because they precisely locate the cloud systems in both space and time. For example, the 
Constant Altitude Plane Position Indicator (CAPPI), used for the assimilation in this study, has a spatial resolution of $1 \mathrm{~km}$ and a temporal resolution of five minutes; this gives the possibility to assimilate radar data frequently and at high horizontal resolution, which is an important aspect of radar data assimilation (RDA) for convective events. Focusing on the complex Italian territory, RDA has shown an important impact on quantitative precipitation forecasts $[9,28,52,60-62]$ for several convective events. A significant advantage of radar data compared to lightning is that radar observations are also available for light to moderate precipitation, while lightning data are scarce in these conditions; furthermore, in the first stages of developing convection, flashes are absent or few, delaying the issuance of severe weather warnings.

This paper shows the impact of radar and lightning data assimilation in the simulation of a severe storm that hit Palermo (Sicily, Italy) on 15 July 2020. The Palermo case study (the geographical position is shown in Figure 1) is representative of a class of deep convective events that develops over Italy, especially on summer afternoons, forced by intense solar radiation in a favorable synoptic-scale environment $[19,20,22,23]$. These events are often localized in space and characterized by intense precipitation, causing floods and flash floods that can become very dangerous when occurring in densely populated urban areas, as in the considered case study. The paper is organized as follows: Section 2 shows the synoptic-scale conditions in which the Palermo flood occurred; Section 3 presents the adopted configuration of the Regional Atmospheric Modeling System at the Institute of Atmospheric Sciences and Climate (RAMS@ISAC) model used in this paper and key results of RAMS@ISAC 3D-Var data assimilation; Section 4 shows the results focusing on the convective analysis of the storm (Section 4.1) and on its predictability (Section 4.2). Conclusions are given in Section 5.

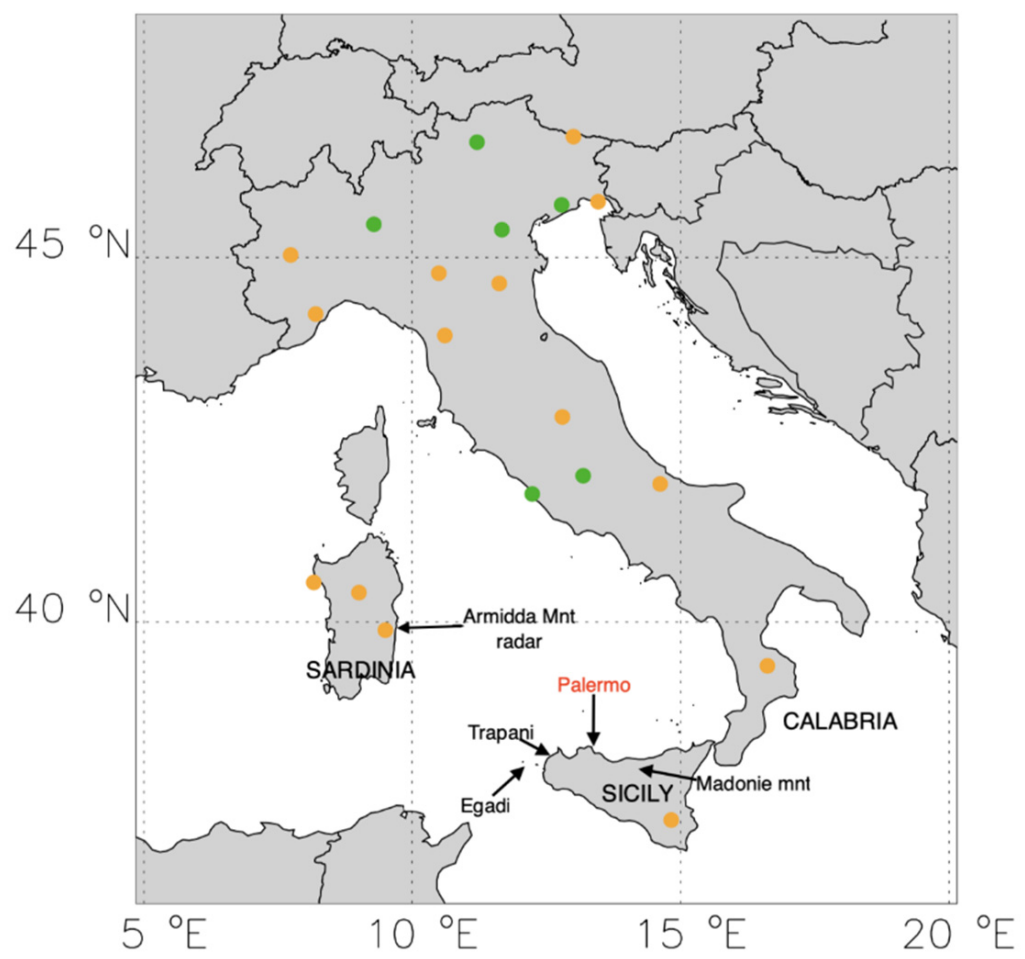

Figure 1. Position of the radars used for assimilation. Green dots are single polarization radars, orange dots are dual polarization radars. Names of locations cited in the text are also shown.

\section{Synoptic Situation and Observation Analysis}

The Palermo storm occurred between 14:00 UTC and 17:00 UTC (i.e., between 16:00 and 19:00 in local time (LT); LT is UTC+2 $\mathrm{h}$ for this time of the year) on 15 July 2020. Palermo is the most populated city in Sicily with 650,000 inhabitants. Consequently, this 
event is particularly relevant as the flash flood hit a densely populated urban area (about 4000 inhabitants per $\mathrm{km}^{2}$ ).

To represent the large-scale conditions during this deep convective event, a synoptic analysis is presented through the European Centre for Medium-Range Weather ForecastIntegrated Forecasting System (ECMWF-IFS) analysis/forecast fields at $0.125^{\circ}$ horizontal resolution both at $500 \mathrm{hPa}$ and $850 \mathrm{hPa}$. The maps are shown (Figure 2) at 12:00 UTC on 14 July and at 12:00 UTC on 15 July; we show the temperature, the geopotential height and the wind vectors.

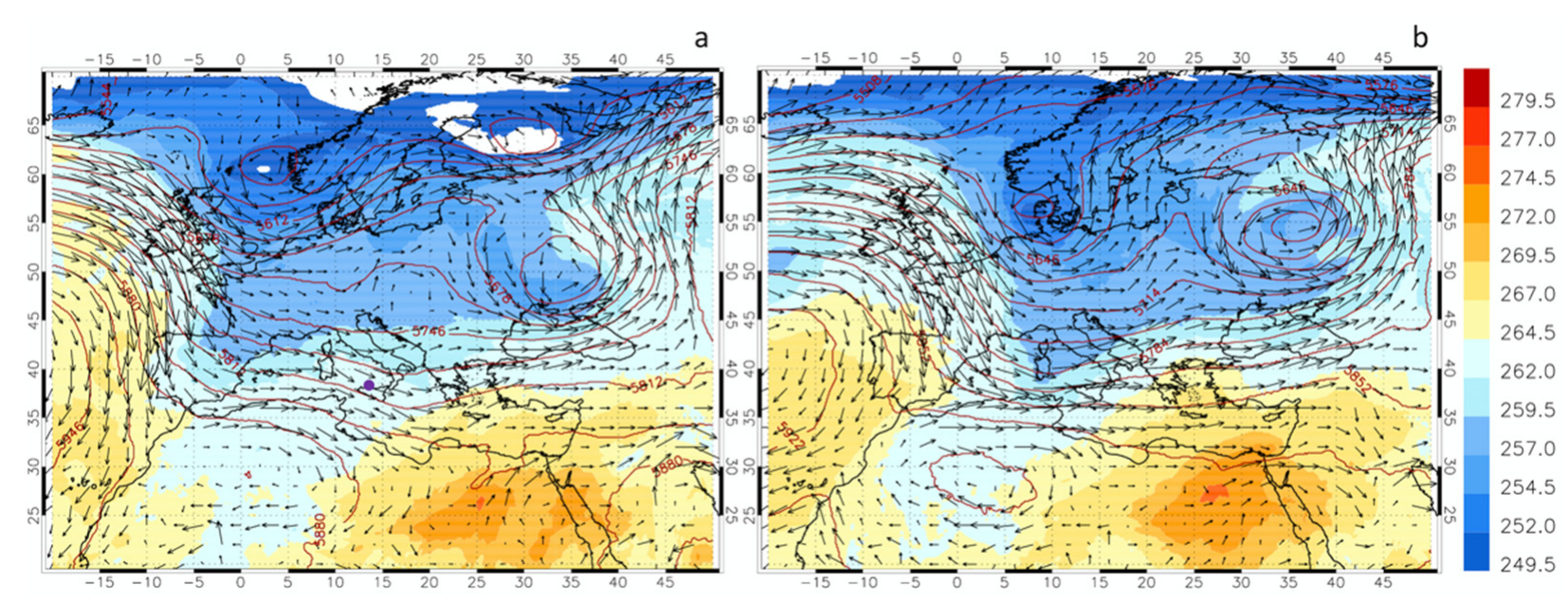

Figure 2. Geopotential height (blue contours), temperature (filled contours), and wind vectors at $500 \mathrm{hPa}$ at 12:00 UTC on 14 July 2020 panel (a), and 12:00 UTC on 15 July 2020 panel (b). A purple dot in panel (a) identifies Palermo's location.

On the left side of the maps at $500 \mathrm{hPa}$, at 12:00 UTC on 14 July (Figure 2a), the synergistic action of the Icelandic low and of the Azores high, that drives currents from $\mathrm{N}-\mathrm{NW}$ over the Mediterranean Basin, is evident.

Another high-pressure center is placed over northwestern Africa; this pattern, together with a cut-off low over Russia, gives the upper-level winds entering the Mediterranean an eastward direction, causing the air masses to reach the southern Italian regions from the west. In the following $24 \mathrm{~h}$ (Figure $2 \mathrm{~b}$ ), the slow eastward shift of the systems can be noticed and, at 12:00 UTC on 15 July, an upper-level trough extends over the southern Tyrrhenian Sea; the upper-level winds remain directed from the west over Sicily. An important synoptic-scale feature of the wind field at $500 \mathrm{hPa}$ is the diffluence of the wind over Sicily. This diffluence favors the development of deep convection and updrafts.

Another important feature of this storm is the humidity at mid-tropospheric levels. Figure 3 shows that the water vapor mixing ratio averaged between a height of 3 and $8 \mathrm{~km}$ over the Mediterranean Sea and surrounding regions at 12:00 UTC on 15 July 2020. The filament of high-water vapor $(>4 \mathrm{~g} / \mathrm{kg}$ ) extending from tropical latitudes towards the Mediterranean is apparent. The anticyclonic and cyclonic centers shown in Figure 2 convey this filament of high-water vapor values towards the southern Mediterranean. The action of the ridge over northern Africa, advecting the water vapor plume towards Sicily, is particularly important for the Palermo flood.

The humid and warm air approaching Sicily, as a consequence of large-scale circulation, is also apparent by comparing the radio soundings taken at Trapani (LICT), on the west coast of Sicily (see Figure 1 for the location), at 00:00 and 12:00 UTC on 15 July 2020 (Figure 4). The dew point temperature and air temperature profiles are much closer at 12:00 UTC compared to 00:00 UTC. At 12:00 UTC, there is an almost saturated layer between 700 and $600 \mathrm{hPa}$ and the atmosphere close to the surface shows an intense vertical temperature gradient, with values close to the dry adiabatic lapse rate. 


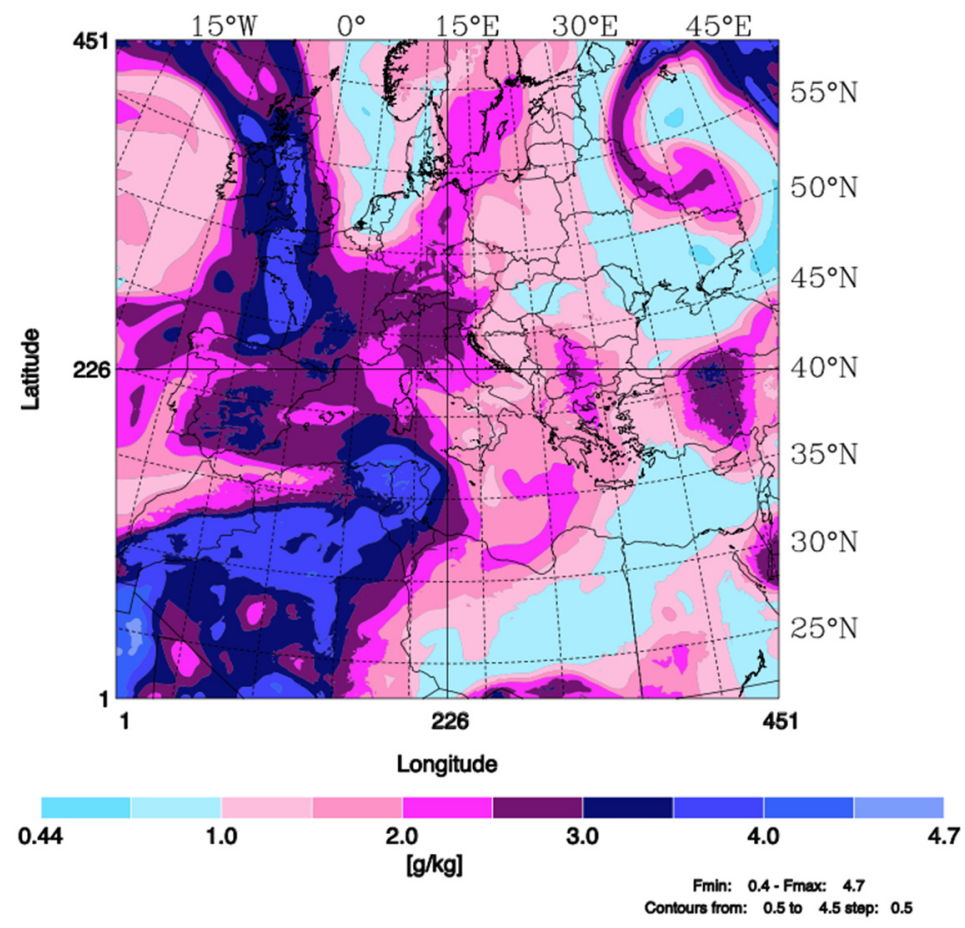

Figure 3. Water vapor mixing ratio averaged between $3 \mathrm{~km}$ and $8 \mathrm{~km}$ at 12:00 UTC on 15 July 2020.

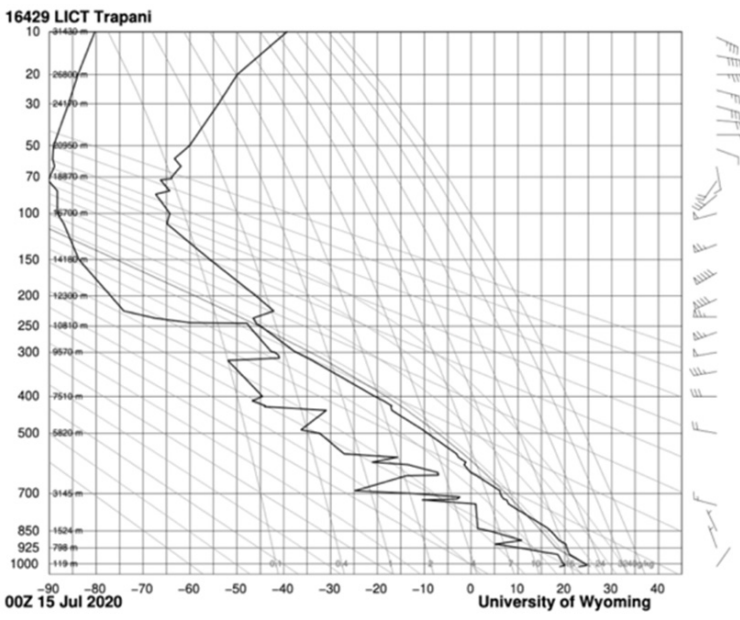

(a)

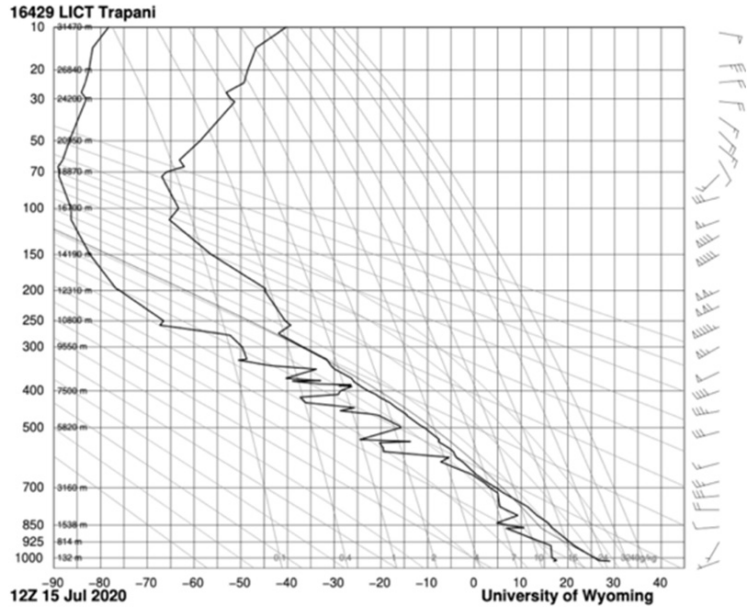

(b)

Figure 4. Radio sounding taken at Trapani (LICT) at 00:00 UTC (a) and 12:00 UTC (b) on 15 July 2020. (Source: Department of Atmospheric Science, University of Wyoming).

Stability indices and other parameters (figures not shown) reveal the unstable environment in which the Palermo case occurred. For example, the convective available potential energy (CAPE) derived from ECMWF analyses at 12:00 UTC on 15 July shows values larger than $3000 \mathrm{~J} / \mathrm{kg}$ over the sea, in the area between Africa, Sardinia and Sicily. The CAPE evaluated from the radio soundings of Figure 4 is $685 \mathrm{~J} / \mathrm{kg}$ at 00:00 UTC and $480 \mathrm{~J} / \mathrm{kg}$ at 12:00 UTC.

Additionally, the sea surface temperature (SST) anomalies for the same day are larger than 3 K over the Tyrrhenian Sea north of Palermo. High values of SST favor the evaporation of the seawater, giving a low-level moisture source for storms developing around the area.

Figure $5 \mathrm{a}, \mathrm{b}$ show the precipitation recorded by rain gauges over Italy between 14:00 UTC and 17:00 UTC, which is the period when the Palermo flood occurred; only rain gauges recording more than $0.2 \mathrm{~mm} / 3 \mathrm{~h}$ are shown. Figure $5 \mathrm{c}$ shows the GPM-IMERG 
observation, which will be discussed in Section 4.2, when considering the precipitation over the sea. Thunderstorms were active in several parts of the Italian peninsula (Figure 5a), with rainfall up to $30-40 \mathrm{~mm} / 3 \mathrm{~h}$; these events are typical of hot summer days, when largescale conditions favor convection development and the land, warmed by the intense solar radiation, acts as a trigger. Rainfall observations over Sicily (Figure $5 b$ ) show thunderstorms (precipitation $>20 \mathrm{~mm} / 3 \mathrm{~h}$ ) occurring in several parts of the island. However, Palermo shows the largest amounts of precipitation $(>100 \mathrm{~mm} / 3 \mathrm{~h})$ with very localized rainfall.

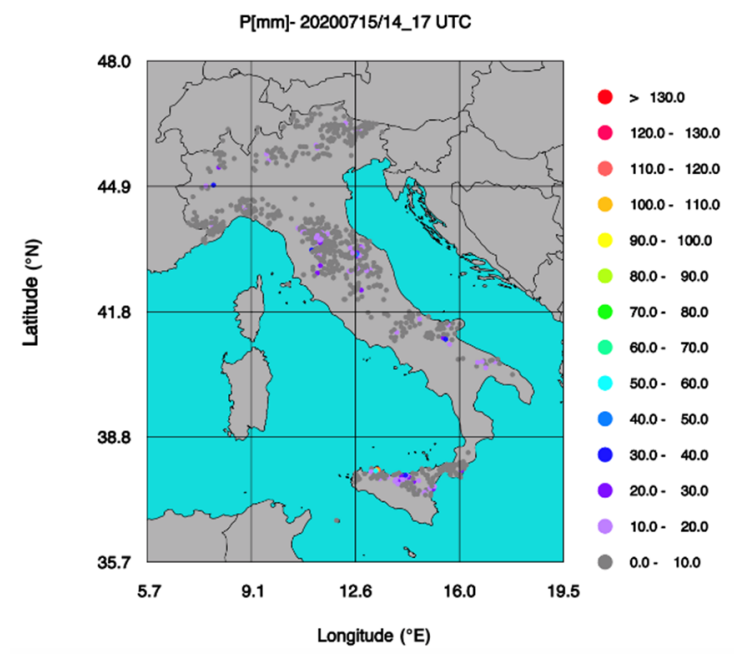

(a)

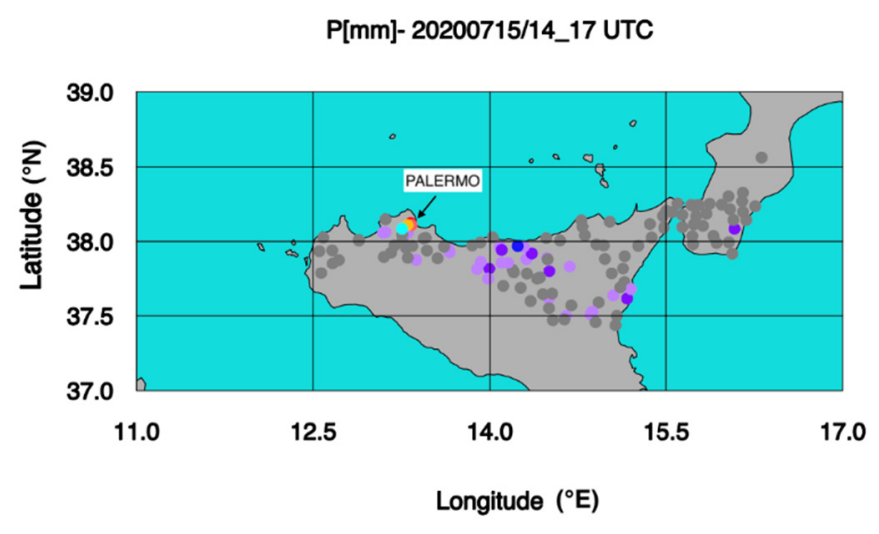

(b)

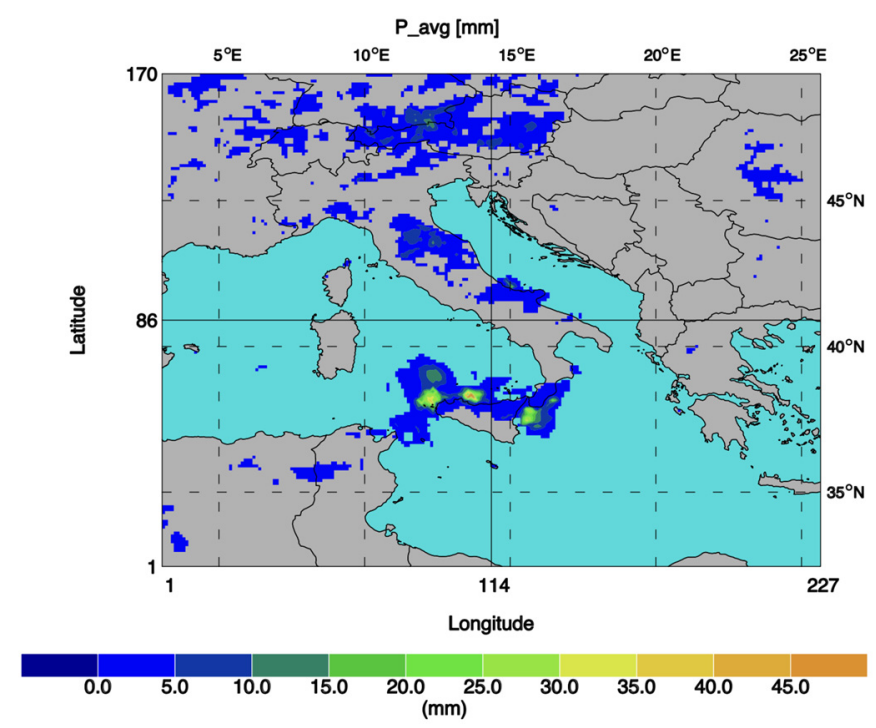

(c)

Figure 5. Observed precipitation between 14:00 and 17:00 UTC on 15 July 2020 from rain gauges for: (a) Italy; (b) Sicily and part of Calabria. The rain gauge network belongs to the Italian regional administrations, whereas the data are collected nationwide by the Department of Civil Protection. (c) Precipitation between 14:00 and 17:00 UTC from GPM-IMERG Final Run.

To further analyze the rainfall affecting Palermo, Table 1 shows the precipitation recorded by three rain gauges in the Palermo urban area. The average amount of precipitation observed between 14:00 UTC and 17:00 UTC was $118 \mathrm{~mm}$. The most intense phase of the precipitation was between 15:00 UTC and 16:00 UTC, when an average of $73.5 \mathrm{~mm}$ was observed. Several parts of the city were flooded and damage to properties was reported. 
Table 1. Rainfall recorded in the period 14:00-17:00 UTC on 15 July 2020 for three rain gauges in Palermo.

\begin{tabular}{|c|c|c|c|c|c|c|c|}
\hline \multirow[t]{2}{*}{ Rain Gauge } & \multirow[t]{2}{*}{ Longitude $\left({ }^{\circ}\right)$} & \multirow[t]{2}{*}{ Latitude $\left({ }^{\circ}\right)$} & \multirow[t]{2}{*}{$\underset{\text { (m) }}{\text { Height }}$} & \multicolumn{3}{|c|}{ Observed Precipitation (mm) } & \multirow{2}{*}{$\begin{array}{c}\text { Total Observed } \\
\text { Precipitation } \\
(\mathrm{mm}) \text { 14:00-17:00 UTC }\end{array}$} \\
\hline & & & & $\begin{array}{c}\text { 14:00-15:00 } \\
\text { UTC }\end{array}$ & $\begin{array}{c}\text { 15:00-16:00 } \\
\text { UTC }\end{array}$ & $\begin{array}{c}\text { 16:00-17:00 } \\
\text { UTC }\end{array}$ & \\
\hline Palermo SIAS & 13.3276 & 38.1298 & 0 & 37.80 & 84.99 & 11.19 & 133.98 \\
\hline Palermo UIR & 13.3350 & 38.1167 & 55 & 47.20 & 66.80 & 1.60 & 115.6 \\
\hline Palermo Zootecnico & 13.3006 & 38.1164 & 120 & 33.60 & 68.70 & 1.20 & 103.5 \\
\hline $\begin{array}{l}\text { Average } \\
\text { Precipitation }\end{array}$ & / & / & / & 39.5 & 73.5 & 4.6 & 117.8 \\
\hline
\end{tabular}

From a meteorological point of view, this case study is interesting, as it was a deep convective event, very localized in space and time, and occurred on a summer afternoon. Data assimilation at the local scale can be very useful to improve the forecast at a short range of such kind of events, which are otherwise difficult to predict.

\section{Data and Method}

\subsection{RAMS@ISAC Configuration and Assimilation Experiments}

In this work, we use the RAMS@ISAC model. This model, maintained and developed at CNR-ISAC, contains several additions to the original RAMS 6.0 model [63]. First of all, in RAMS@ISAC, the WSM6 microphysics scheme [64] has been included [65]. Furthermore, the model is able to forecast lightning, since the method proposed by Dahl et al. [66] has been implemented [67]. An important upgrade introduced in the model is the implementation of a 3D-Var data assimilation system [68]. The RAMS@ISAC 3D-Var can assimilate radar observations [52], GPS-ZTD [69], radio soundings, wind profiler data [68] and lightning data (the method is described in this article for the first time). Lightning data can also be assimilated into the RAMS@ISAC model through nudging, using the Fierro et al. [43,44] method, whose implementation in RAMS@ISAC is described by Federico et al. [51].

The model configuration of this paper provides simulations on a grid with $3 \mathrm{~km}$ horizontal resolution (Figure 6). Grid details are shown in Table 2. The horizontal grid has $635 \times 635$ grid points, while the vertical grid has 50 levels, extending from the ground to a model top of about $25,600 \mathrm{~m}$. The vertical coordinates are terrain following [63].

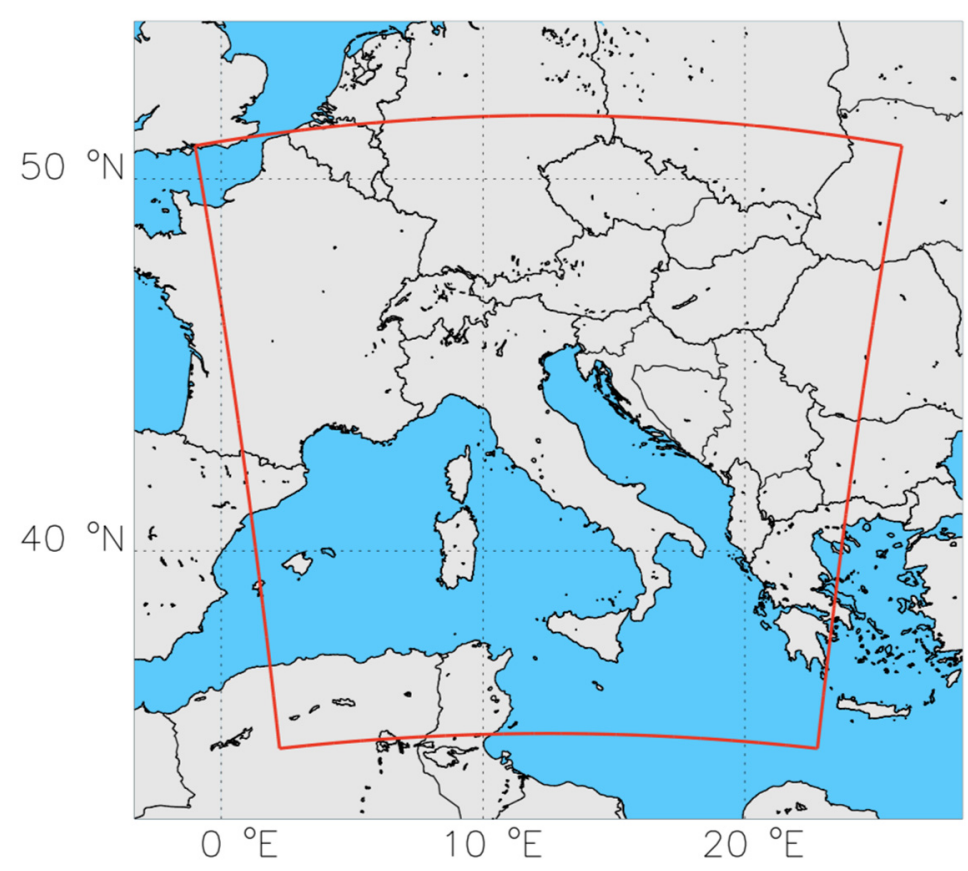

Figure 6. RAMS@ISAC model domain. 
Table 2. RAMS@ISAC grid parameters. NNXP and NNYP are model grid points in both WE and SN directions, while NNZP indicates the number of vertical levels. DX and DY are the grid spatial dimensions in the WE and SN directions, respectively. Lx, Ly and Lz represent the domain extension in WE and SN directions and in the vertical direction, respectively. CENTLON and CENTLAT indicate the coordinates of the grid center.

$\begin{array}{cc}\text { NNXP } & 635 \\ \text { NNYP } & 635 \\ \text { NNZP } & 50 \\ \text { Lx } & 1905 \mathrm{~km} \\ \text { Ly } & 1905 \mathrm{~km} \\ \text { Lz } & 25,648 \mathrm{~m} \\ \text { DX } & 3 \mathrm{~km} \\ \text { DY } & 3 \mathrm{~km} \\ \text { CENTLAT }\left(^{\circ}\right) & 43.0 \mathrm{~N} \\ \text { CENTLON }\left({ }^{\circ}\right) & 12.5 \mathrm{E}\end{array}$

The main physical parameterization schemes employed in this study include: the WSM6 microphysical scheme [64]; the LEAF3 [70] model for land surface processes; the turbulence scheme following the Smagorinsky [71] horizontal diffusion and the Mellor and Yamada [72] vertical diffusion parameterizations; the radiation scheme for short-wave and long-wave radiation parameterizations following Chen and Cotton [73].

The model was initialized using initial and lateral boundary conditions coming from the IFS global model of the ECMWF. In particular, we employed the $0.125^{\circ}$ operational analysis/forecast cycle, issued at 12:00 UTC on 14 July 2020.

In this study, we use two sources of data for assimilation at the local scale: lightning data and radar reflectivity data. For the case study considered in this paper, seven assimilation experiments were conducted, using one or both sources of data described above. A summary of these experiments is reported in Table 3. All simulations covered an $11 \mathrm{~h}$ period, i.e., from 06:00 UTC to 17:00 UTC.

Analyses are computed every $30 \mathrm{~min}$, which is more frequent than 3D-Var analyses with the RAMS@ISAC model in previous studies [52] because high-frequency cycling gives a larger amount of information from these observations with more frequent smaller adjustments at finer scales [46]. For each analysis, we collect lightning in the $30 \mathrm{~min}$ before the analysis time. Radar observations are taken within five minutes from the analysis time and are considered instantaneous.

Table 3. RAMS@ISAC simulations. All simulations refer to the 15 July 2020. The INIT column shows the simulation start time, ASSIM_END shows the end of the assimilation phase, END is the simulation ending time. The LDA column shows if lighting is assimilated, and the parameter adjusted. The RDA column shows if radar data are assimilated, and the parameter adjusted.

\begin{tabular}{cccccc}
\hline Acronym & INIT (UTC) & $\begin{array}{c}\text { ASSIM_END } \\
\text { (UTC) }\end{array}$ & END (UTC) & LDA & RDA \\
\hline CTRL & $06: 00$ & $/$ & $17: 00$ & No & No \\
\hline RAD & $06: 00$ & $14: 00$ & $17: 00$ & No & $\begin{array}{c}\text { Yes } \\
\text { (qv adjusment) }\end{array}$ \\
\hline LIGHT & $06: 00$ & $14: 00$ & $17: 00$ & $\begin{array}{c}\text { Yes } \\
\text { (qv adjusment) }\end{array}$ & No \\
\hline RL & $06: 00$ & $14: 00$ & $17: 00$ & $\begin{array}{c}\text { Yes } \\
\text { (qv adjusment) }\end{array}$ & $\begin{array}{c}\text { Yes } \\
\text { (qv adjusment) }\end{array}$ \\
\hline RL7.5h & $06: 00$ & $13: 30$ & $17: 00$ & $\begin{array}{c}\text { Yes } \\
\text { (qv adjusment) }\end{array}$ & $\begin{array}{c}\text { Yes } \\
\text { (qv adjusment) }\end{array}$ \\
\hline RL7.0h & $06: 00$ & $13: 00$ & $17: 00$ & $\begin{array}{c}\text { Yes } \\
\text { (qv adjusment) }\end{array}$ & (qv adjusment) \\
\hline RL6.5h & $06: 00$ & $12: 30$ & $17: 00$ & $\begin{array}{c}\text { Yes } \\
\text { (qv adjusment) }\end{array}$ & (qv adjusment) \\
\hline
\end{tabular}


The seven experiments are as follows. The first simulation is CTRL with no lightning or radar reflectivity data assimilation. RAD simulation assimilates the radar data every 30 min until 14:00 UTC, then a $3 \mathrm{~h}$ free forecast is done. LIGHT simulation assimilates lightning through 3D-Var every $30 \mathrm{~min}$ until 14:00 UTC, then a $3 \mathrm{~h}$ forecast follows. RL forecast assimilates both lightning and radar reflectivity every 30 min until 14:00 UTC, then the $3 \mathrm{~h}$ forecast follows. The following three experiments, RL7.5 h, RL7.0h and RL6.5, are carried out by assimilating radar reflectivity and lightning data together, as in RL, and differ in the duration of the assimilation period. In RL7.5h, RL7.0h and RL6.5, the assimilation phase lasts $7 \mathrm{~h}$ and $30 \mathrm{~min}, 7 \mathrm{~h}$ and $6 \mathrm{~h}$ and $30 \mathrm{~min}$, respectively. The last three experiments are designed to investigate the predictability of the event.

\subsection{Lightning and Radar Data}

For lightning, we make use of the Lightning Detection Network (LINET) [74]. This network observes both intra-cloud (IC) and cloud-to-ground (CG) strokes. IC and CG strokes are distinguished through the time of arrival (TOA) method [75], which permits the calculation of the height of IC strokes too. The LINET system provides the following data for each stroke: date and time of occurrence, latitude, longitude, lightning type (IC or CG), lightning amperage and stroke height for IC strokes. All discharges recorded within a $1 \mathrm{~s}$ period and within a $10 \mathrm{~km}$ radius are considered as a single flash for data assimilation [67]. Only the position and time of flashes are used in LDA.

As regards radar, we employ data from the Italian Radar Network, coordinated by the Italian Department of Civil Protection (DPC). This network includes 23 radars over the Italian territory, 20 of which operate at the $\mathrm{C}$ band, while 3 operate at the $\mathrm{X}$ band. Only the 20 C-band radars are used for RDA (see Figure 1). We assimilate the CAPPI of the radar reflectivity factor, operationally provided by the DPC. The considered CAPPIs refer to 7 altitude levels, namely from 2000 to 8000 m, by 1000 m increments. Data quality control is performed by the DPC through a process including nine steps and is described in detail by Vulpiani et al. [76], Petracca et al. [77] and references therein.

\subsection{Radar and Lightning 3D-Var Data Assimilation}

Lightning and radar reflectivity data are assimilated in RAMS@ISAC through pseudoprofiles of the water vapor mixing ratio and the first step is to generate these profiles. For lightning data assimilation (LDA), the process is straightforward: the pseudo-profile is a saturated profile between the lifting condensation level (LCL) and the $-25{ }^{\circ} \mathrm{C}$ isotherm. The LCL is computed by the model background temperature and humidity and pseudoprofiles are computed at model grid-points by remapping lightning data to the model grid. The method of assimilating lightning by pseudo-profiles of humidity in a 3D-Var data assimilation system has been applied in the literature $[46,48]$, however, it is presented in this paper for the first time with RAMS@ISAC.

For radar reflectivity data assimilation (RDA), we use the method proposed by Caumont et al. [78], which considers pseudo-profiles of relative humidity. In this paper, we give some details about the method, but the reader is referred to Federico et al. [52] for a detailed description of its implementation in RAMS@ISAC. In the same paper, the formulation of a forward observation operator for radar reflectivity data assimilation is given in the supplemental material. This method is a two-step process: first, using a Bayesian approach inspired by the Goddard profiling algorithm (GPROF; $[79,80])$, pseudo-profiles of relative humidity are generated; second, the pseudo-profiles of relative humidity are assimilated in RAMS@ISAC by 3D-Var. RDA uses the CAPPI of radar reflectivity as observations. CAPPIs are available at 2, 3, 4, 5, 6, 7 and $8 \mathrm{~km}$ a.s.l. This represents a substantial upgrade of the RDA by Federico et al. [52], where CAPPIs were available at 2, 3, and $5 \mathrm{~km}$. CAPPIs have a $1 \mathrm{~km}$ horizontal resolution, but they are resampled at a $5 \mathrm{~km}$ horizontal resolution to partially account for the correlation of the observation error. Pseudo-profiles of relative humidity, used in RDA, are converted into profiles of the water vapor mixing ratio, which is the variable used in RAMS@ISAC 3D-Var. 
The double of the cost function is given by:

$$
2 J(x)=\left(x-x_{b}\right)^{T} \mathbf{B}^{-1}\left(x-x_{b}\right)+\left(y_{o}-\mathrm{H}(x)\right)^{T} \mathbf{R}^{-1}\left(y_{o}-\mathrm{H}(x)\right)
$$

where $x$ is the basic state vector giving the analysis $\left(x_{a}\right)$ after the minimization of the cost function, $\mathbf{B}$ is the background error matrix, $\mathbf{R}$ is the observation error matrix, $y_{o}$ are the pseudo-profiles of the water vapor mixing ratio and $\mathrm{H}$ is the forward observation operator, which simply extracts the water vapor mixing ratio profiles corresponding to the pseudo-observations.

For the sake of clarity, we recall how the observation $y_{o}$ and forward observational operator for lightning and radar reflectivity data assimilation are computed. Lightning is remapped onto the RAMS@ISAC grid and this process gives a two-dimensional matrix, defined on the RAMS@ISAC grid, whose values are 1 or 0 depending on if lightning has been observed or not in a grid cell centered at the grid point in the last $30 \mathrm{~min}$. For each grid point with lightning data occurrences, the vertical profile $y_{0}$ is computed by:

$$
y_{0}: \begin{cases}N O D A T A & z<z_{L C L} \\ q_{s} & z_{L C L} \leq z \leq z_{-25^{\circ} \mathrm{C}} \\ N O D A T A & z>z_{-25^{\circ} \mathrm{C}}\end{cases}
$$

where $q_{s}$ is the saturation mixing ratio, $z_{L C L}$ is the height of the lifting condensation level computed from the background and $z_{-25^{\circ} \mathrm{C}}$ is the height of the $-25^{\circ} \mathrm{C}$ isotherm from the background.

As the water vapor mixing ratio is a dependent model variable, the forward observation operator for lightning $(\mathrm{H})$ is simple: it is an operator that extracts the model profile of the water vapor mixing ratio corresponding to the specific grid point where lightning has been observed.

For radar reflectivity data assimilation, the radar is resampled on a $5 \mathrm{~km}$ horizontal grid resolution. The vertical grid is given by the levels from $2 \mathrm{~km}$ to $8 \mathrm{~km}$ every $1 \mathrm{~km}$. We will refer to this grid as the radar grid. The model fields necessary for radar data assimilation are interpolated onto this grid. The method of Caumont et al. [78] is used to compute pseudo-profiles of relative humidity for each grid column where reflectivity is observed or simulated by the model. Here, the forward observation operator converting the background into reflectivity is needed. The details of this operator are given in the supplemental material of Federico et al. [52] (Section S8). Once pseudo-profiles of relative humidity are computed, they are converted into the water vapor mixing ratio using the background pressure and temperature, and a pseudo-profile of the water vapor mixing ratio is obtained. Then, similarly to lightning data assimilation, the forward observation operator for radar reflectivity data assimilation $(\mathrm{H})$ is simple: it is an operator that extracts the background profile of the water vapor mixing ratio corresponding to the grid point (of the radar grid) where radar reflectivity is observed or simulated. In the 3D-Var formulation, the background error matrix $\mathbf{B}$ is decomposed in the three spatial directions $\mathbf{B}_{\mathbf{x}}, \mathbf{B}_{\mathbf{y}}, \mathbf{B}_{\mathbf{z}}$. The $\mathbf{B}_{\mathbf{x}}, \mathbf{B}_{\mathbf{y}}$ matrices spread the analysis adjustment in the horizontal plane, applying a Gaussian decorrelation function, whose length scale depends on the level, and are computed with the NMC method [81,82]. To have a background error matrix representative of the period, the NMC is applied to 15 days, from 1 to 15 July 2020, considering RAMS@ISAC $12 \mathrm{~h}$ and $24 \mathrm{~h}$ forecasts verifying at the same time (12:00 UTC) on each day. This horizontal length scale is less than $10 \mathrm{~km}$ below a height of $2 \mathrm{~km}$ but increases at higher levels. However, to maintain the innovation at the local scale, the horizontal length scale is reduced to $20 \mathrm{~km}$ if the NMC method gives higher values.

The background matrix in the vertical direction, $\mathbf{B}_{\mathbf{z}}$, accounts for the error of the water vapor field, as well as for the error decorrelation length scale in the vertical direction, which is modeled by a Gaussian function. The error of the water vapor mixing ratio decreases with height starting from a value of $3 \mathrm{~g} / \mathrm{kg}$ close to the surface. The error at a $3 \mathrm{~km}$ height is around $0.5 \mathrm{~g} / \mathrm{kg}$. The vertical decorrelation length scale is less than $100 \mathrm{~m}$ close to the 
ground and increases in the upper troposphere, reaching a maximum of $500 \mathrm{~m}$ at a height of $6-8 \mathrm{~km}$.

The observation error matrix is diagonal with elements along the diagonal being half of the error used in $\mathbf{B}_{\mathbf{z}}$ at the same level. This choice gives more credit to the observations compared to the background and it is motivated by the poor performance of the forecast over Palermo.

An important difference between LDA and RDA is that while LDA can only increase the water vapor in the RAMS@ISAC, RDA can both increase and decrease the water vapor content in the model. However, the subtraction of spurious convection for this case study is negligible, as shown by the example discussed in the next section.

The radar over Sicily was in maintenance for the day when the Palermo flood occurred and no radar data over Sicily were available. Nevertheless, an important role for the improvement of the rainfall forecast over Sicily was played by the radar located over central-east Sardinia (Mount Armidda radar).

\section{Results}

\subsection{Impact of Data Assimilation on the Water Vapor Field}

In this section, we discuss the innovations given by the data assimilation of lightning and/or radar reflectivity. Figure 7 shows the adjustment given by RDA, LDA and by their combination to the relative humidity field at about $3000 \mathrm{~m}$ in the terrain following the coordinate system of RAMS@ISAC at 13:30 UTC, when the convection started to the southwest of Palermo.

The RDA (Figure 7a) shows adjustments for convection occurring over the Central Apennines (adjustments around 25\%), on the Italian mainland, with some convective spots over northern and southern Italy. There are few negative values, often close to the positive adjustments, caused by small spatial errors in the position of the convective activity in the CTRL forecast.

It is important to note the increase in relative humidity over the southern Tyrrhenian Sea between Sardinia and Sicily. This adjustment is caused by the assimilation of reflectivity of the radar over central-east Sardinia (Mnt. Armidda radar) and is an important feature for the improvement of the precipitation forecast over Palermo, as shown in the next section.

From LDA (Figure 7b), it is apparent that convection started west of Palermo and over the sea to the northwest of the city. Convective activity occurred over the sea between Sicily and Tunisia, along the filament of high humidity conveyed over the Mediterranean by the general circulation of this event (Figure 3). There are positive adjustments in the Apennines over northern and southern Italy.

The adjustment of the combined effect of LDA and RDA (Figure 7c) shows the synergistic action of the two types of data for the Palermo case. As mentioned above, radar reflectivity data are missing over Sicily because of the radar maintenance; nevertheless, LDA gives the humidity that triggered convection around the city. Additionally, lightning gives an important humidity adjustment between Sicily and Tunisia, an area not covered by the Italian radar network. Radar observations over Sardinia add water vapor to the CTRL simulation between Sicily and Sardinia, which is not apparent in LDA in Figure 7b because flashes did not occur over this area at 13:30 UTC. An inspection of the lightning activity at 14:00 UTC (not shown), confirms that flashes occurred in this area.

To better understand the impact of LDA and RDA on the simulation of water vapor for the Palermo case, Figure 8 shows the difference in the water vapor mixing ratio between the simulations RAD and CTRL (Figure 8a) and between the simulations LIGHT and CTRL (Figure $8 b$ ). These differences are shown at 14:00 UTC, before the assimilation cycle of 14:00 UTC, at about $3000 \mathrm{~m}$ in the terrain following the coordinate system of RAMS@ISAC. Therefore, the last adjustments given by RDA and LDA at this level are those of Figure 7a,b, which are propagated by the model for half an hour. 


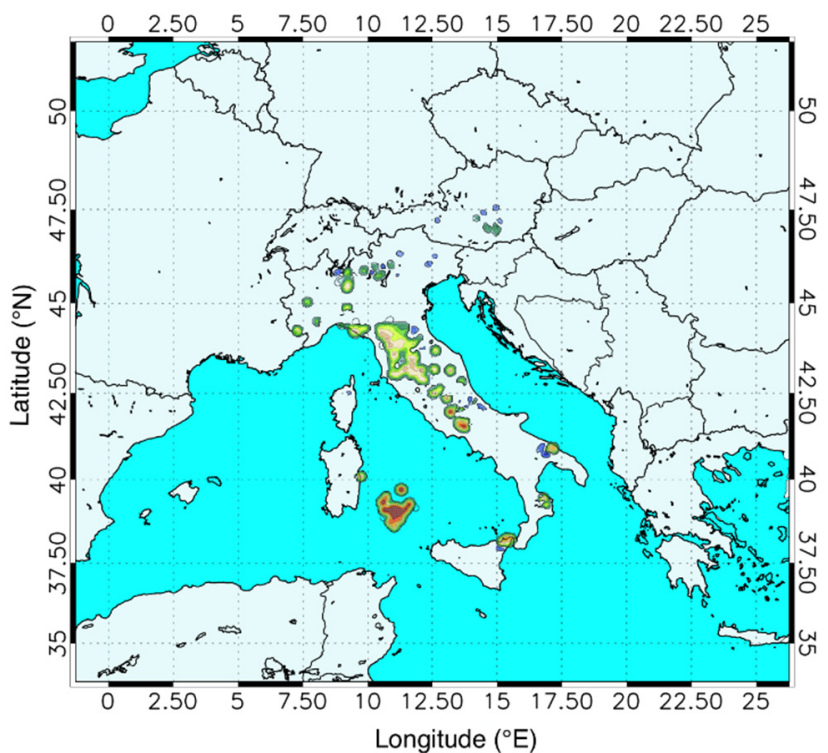

(a)

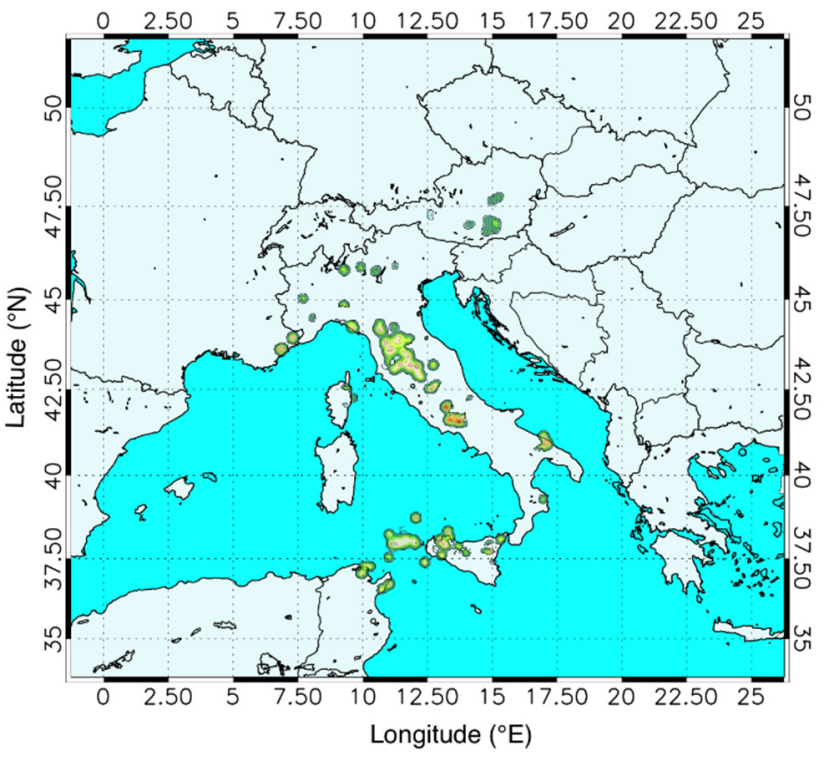

(b)

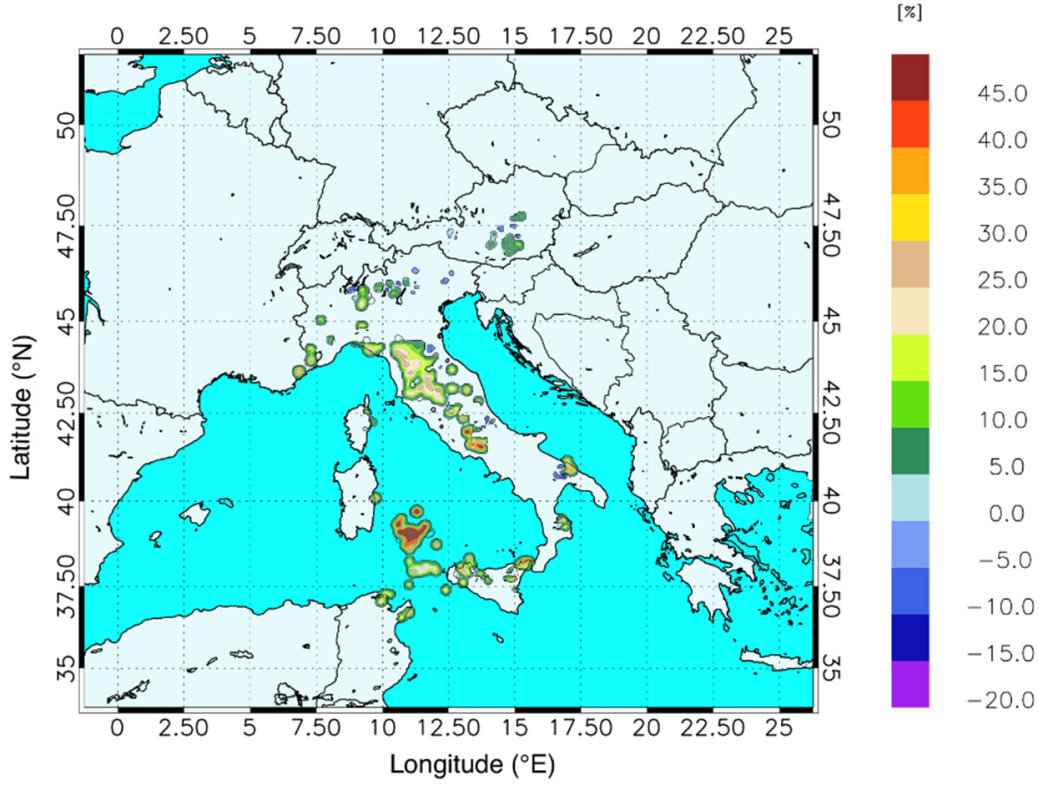

(c)

Figure 7. Analysis innovations for relative humidity at 13:30 UTC and at a height of $2896 \mathrm{~m}$ in the terrain following the coordinate system of RAMS@ISAC for: (a) radar reflectivity data assimilation; (b) lightning data assimilation; (c) radar reflectivity and lightning data assimilation.

The RDA mainly shows two positive contributions (water vapor added to the CTRL forecast): one over the western part of the domain shown in Figure 8a, and the second over the northeast tip of Sicily, also extending towards Calabria, which is the southernmost region of the Italian peninsula. Comparing Figures $7 \mathrm{a}$ and $8 \mathrm{a}$, the impact of the advection of water vapor added by RDA to the forecast is also evident. In particular, the water vapor added by RDA is advected towards Palermo, increasing the humidity around the area. Therefore, even if the radar over Sicily was not available for this event, the water vapor adjustment provided by the radar in Sardinia was advected towards Sicily, giving more favorable conditions for convection development, compared to the CTRL forecast.

The positive contribution of relative humidity given by RDA over the northeastern tip of Sicily and over Calabria is caused by the assimilation of the reflectivity observations of the radar in Calabria. 


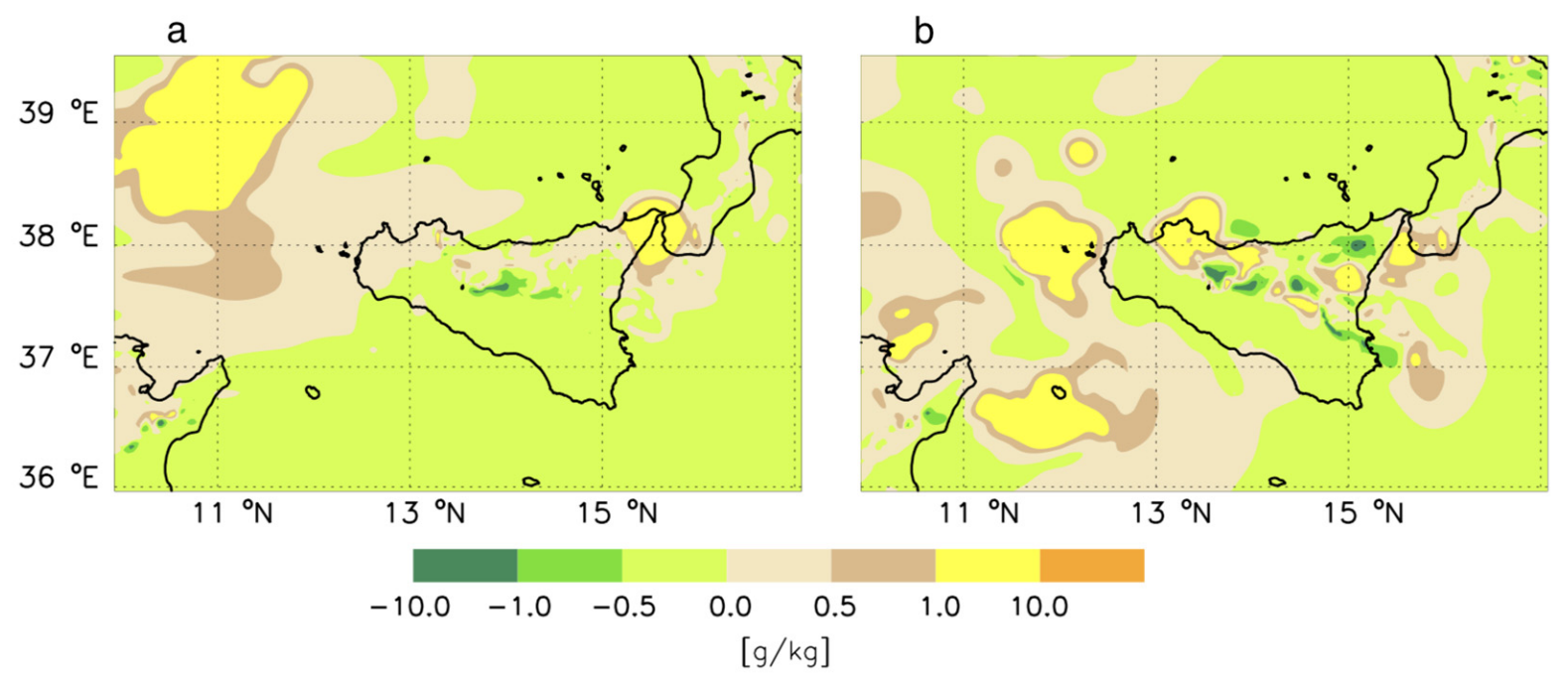

Figure 8. Difference between the water vapor mixing ratio $(\mathrm{g} / \mathrm{kg}$ ) of the RAD simulation and CTRL (a) and between the water vapor of LIGHT simulation and CTRL (b). Both panels are at 14:00 UTC on 15 July 2020 and at the $2896 \mathrm{~m}$ level in the terrain-following coordinate system of RAMS@ISAC.

Considering the impact of LDA, the spotty pattern of the difference between LIGHT and CTRL forecasts is noticed (Figure 8b), which is typical of summer convection. An important relative humidity adjustment of LDA is that around Palermo, which is caused by the beginning of the convective activity around the city at 13:30 UTC (Figure 7b).

\subsection{Precipitation and Convective Activity}

In this section, we show the results for the simulations assimilating lightning and/or radar reflectivity from 06:00 to 14:00 UTC on 15 July 2020, while the precipitation forecast is considered between 14:00 UTC and 17:00 UTC, which is the most intense phase of the storm over Palermo. As an important aspect of this case study is its predictability (discussed in the next section), it is worth noticing that the forecast with lightning and/or radar reflectivity data assimilation would have been available at 14:30 UTC, when rainfall had already started over Palermo. In fact, an average of $40 \mathrm{~mm}$ was observed between 14:00 and 15:00 UTC (Table 1). Nevertheless, the forecast would have been available half an hour before the most intense rainfall over the city, which occurred between 15:00 UTC and 16:00 UTC.

The CTRL forecast, shown in Figure 9a, shows a precipitation swath over eastern Sicily, which is overestimated for this $3 \mathrm{~h}$ period (Figure $5 \mathrm{~b}$ ), and misses the event over Palermo. This forecast is like that issued by the Department of Civil Protection on the day before this case study and gives an alert over the eastern part of Sicily. While the rainfall over eastern Sicily is overestimated by the CTRL forecast between 14:00 UTC and 17:00 UTC, the hours following those considered in this section were characterized by high rainfall rates in eastern Sicily $(40-50 \mathrm{~mm} / 1 \mathrm{~h})$. Therefore, the CTRL forecast anticipated the real occurrence of an intense rainfall event over eastern Sicily.

The RAD forecast, shown in Figure 9b, does not improve the rainfall prediction over Palermo. There are, however, effects of radar data assimilation, such as: (a) the rainfall over the sea to the northwest of Sicily; (b) a precipitation spot over southern Calabria; (c) an increase in rainfall swath from $14^{\circ} \mathrm{E} ; 37.8^{\circ} \mathrm{N}$ towards the eastern coast of Sicily compared to CTRL. This precipitation swath is shown by the observations (Figure 5b). The rainfall over Calabria is likely overestimated by RAD even if rain gauges show a moderate precipitation $(20-30 \mathrm{~mm} / 3 \mathrm{~h})$ over this area. It is worth recalling that radar reflectivity data were not available over Sicily for this case study and the differences between the background and RAD precipitation are caused by the assimilation of the radars in Sardinia and Calabria. 
a

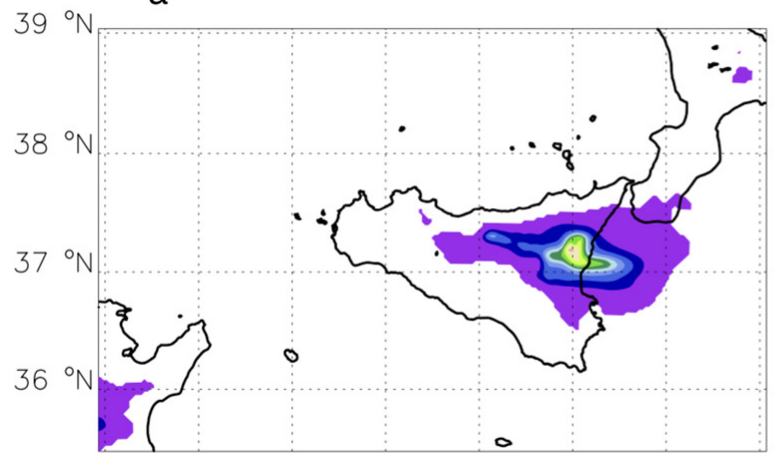

C

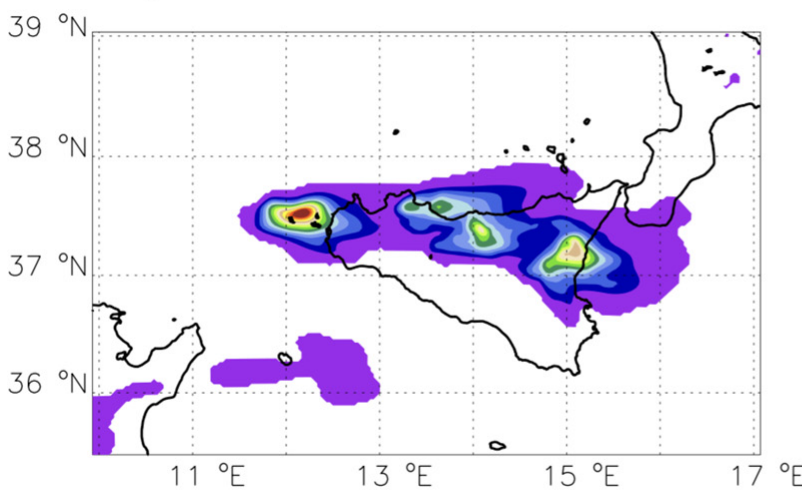

b

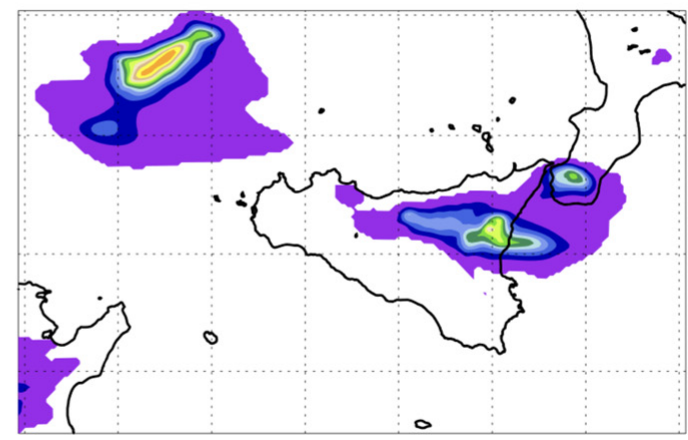

130

120

110

100

90

80

70

d

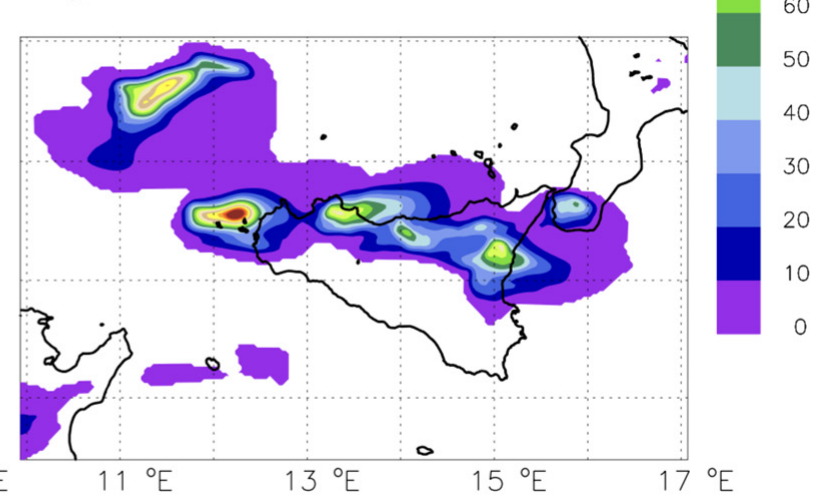

Figure 9. Rainfall forecast (mm) between 14:00 and 17:00 UTC for: (a) CTRL; (b) RAD; (c) LIGHT; (d) RL.

Lightning data assimilation substantially improves the precipitation forecast with a rainfall of $55 \mathrm{~mm} / 3 \mathrm{~h}$ over Palermo (Figure 9c). This forecast suggests a possible moderateintense precipitation over the city in the following couple of hours. The simulated precipitation is about half of the $118 \mathrm{~mm} / 3 \mathrm{~h}$ observed, nevertheless the location of the precipitation spot is precise. This result is in line with many experiments showing the ability of LDA to correctly represent the position of intense convective events over Italy [51,53,54].

The LIGHT forecast does not improve the rainfall overestimation over eastern Sicily.

The best precipitation forecast is given by RL (Figure $9 \mathrm{~d}$ ). The $90 \mathrm{~mm} / 3 \mathrm{~h}$ forecast over Palermo between 14:00 and 17:00 UTC, while underestimated compared to the observed precipitation $(118 \mathrm{~mm} / 3 \mathrm{~h})$, shows the occurrence of an intense precipitation event over the city center, with the maximum rainfall location very well predicted. The forecast over the Madonie Mountains is also well represented and correctly reduced compared to the LIGHT forecast, which overestimated the rainfall over this mountain range. Additionally, RL improves the rainfall forecast over Calabria compared to LIGHT and RAD; in this case, the RL precipitation level is in between those of LIGHT and RAD.

An interesting point about the forecasts presented in this section is the synergistic action of the RDA and LDA. The rainfall over Palermo predicted by RL $(90 \mathrm{~mm} / 3 \mathrm{~h})$ is larger than the sum of the forecasts given by LIGHT $(55 \mathrm{~mm} / 3 \mathrm{~h})$ and RAD $(<10 \mathrm{~mm} / 3 \mathrm{~h})$. This behavior is explained by the results shown in Figure 8, and by the nonlinear interactions occurring in precipitation processes. The RDA adds humidity to the CTRL simulation, to the west and northwest of Sicily, but the amount is not enough to force a deep convection development over Palermo. LDA is able to trigger the deep convection over the city, but the amount of rainfall predicted is small. However, when convection is triggered by LDA in the presence of the additional water vapor added by RDA, the amount of rainfall over Palermo is reasonably predicted.

A qualitative verification of the two precipitation maxima over the sea, to the west of Sicily (forced by LDA, Figure 9c) and to the northwest of Sicily (forced by RDA, Figure 9b), was carried out by the precipitation of the GPM-IMERG [83] dataset for the period 14:00- 
17:00 UTC (Figure 5c). The IMERG rainfall shows a maximum over the sea west of Sicily of the same order of that recorded over the sea beside Palermo $(70 \mathrm{~mm} / 3 \mathrm{~h})$, while the precipitation over the city of Palermo is not well represented by IMERG. In addition, the maximum over the sea, to the northwest of Sicily, is much lower $(10 \mathrm{~mm} / 3 \mathrm{~h})$. Therefore, based on the GPM-IMERG precipitation dataset, we conclude that the rainfall over the sea west of Sicily is well represented by LIGHT and RL forecasts, while the precipitation to the northwest of Sicily is overestimated by RAD and RL forecasts.

To further analyze the differences among the forecasts discussed in this section, Figure 10 shows the latitude-height cross section corresponding to Palermo's longitude $\left(13.38^{\circ} \mathrm{E}\right)$ at 14:30 UTC, when convection was active over the city.

(a)

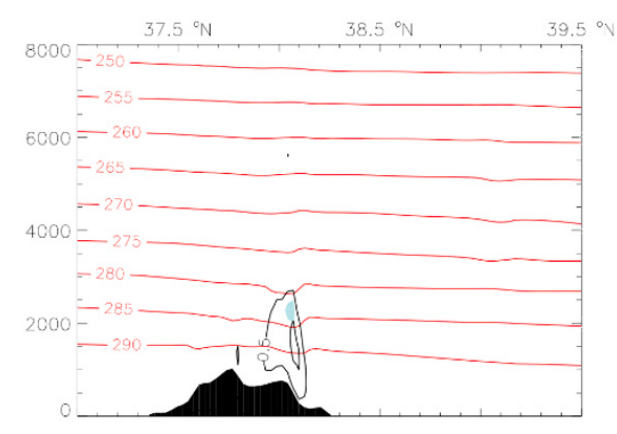

(c)

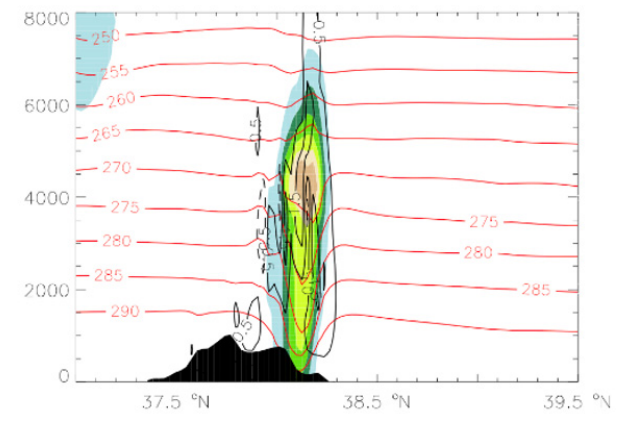

(b)

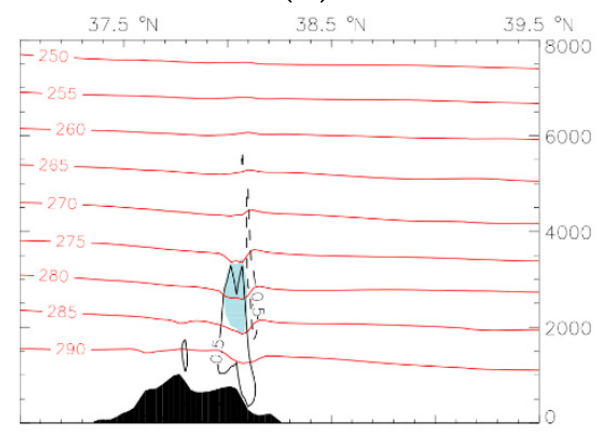

(d)

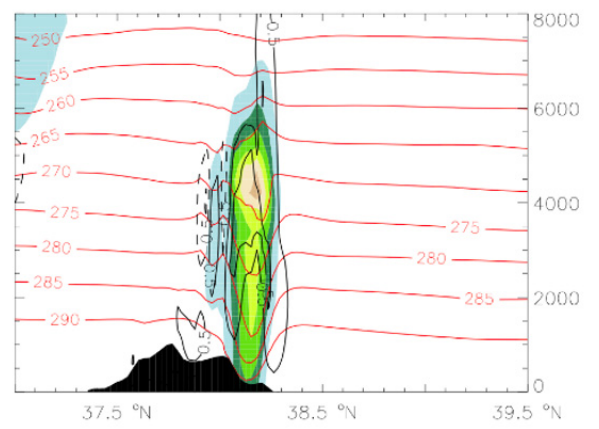

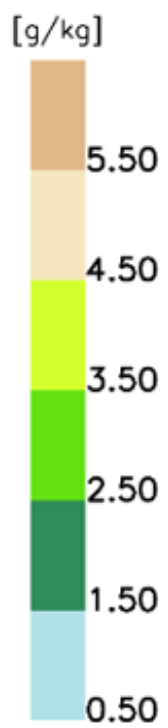

0.50

Figure 10. Latitude-height cross sections $\left(13.38^{\circ} \mathrm{E}\right.$ longitude, i.e., corresponding to Palermo's urban area) of total condensate (filled contours, $\mathrm{g} / \mathrm{kg}$ ), temperature (red contours, $\mathrm{K}$ ) and vertical velocity (black contours, solid for updrafts and dashed for downdrafts, m/s) for (a) CTRL; (b) RAD; (c) LIGHT; (d) RL. All panels are at 14:30 UTC.

To represent convection, we consider the total condensate, the vertical velocity and the temperature. The difference between the forecasts assimilating lightning (LIGHT, Figure 10c, and RL, Figure 10d) and those not assimilating lightning (CTRL, Figure 10a, and RAD, Figure 10b) is apparent, with deep convection well developed for the former and shallow convection for the latter.

For LIGHT (Figure 10c) and RL (Figure 10d), the maximum updraft for the cross section of Figure 10 is larger than $3 \mathrm{~m} / \mathrm{s}$, the total condensate is greater than $5.5 \mathrm{~g} / \mathrm{kg}$ and the temperature perturbations are greater than $5 \mathrm{~K}$ in the lower part of the cloud, where evaporative processes of hydrometeors occur.

The RDA is not able to trigger the deep convection of the Palermo case and the cloud that develops over the city barely reaches $4 \mathrm{~km}$ in height.

The fields of the cross section of Figure 10 are similar for RL and LIGHT and cannot explain their precipitation difference (Figure 9c,d). To consider this point, Figure 11 shows the same fields of Figure 10 at 16:00 UTC, at the end of the intense precipitation phase over Palermo. The convection over Palermo is more intense in the RL (Figure 11b) simulation compared to LIGHT (Figure 11a). This result, along with Figure 10, clarifies the differences between the forecasts: RDA is not able to trigger the deep convection over Palermo because 
of the missing of radar data over Sicily, nevertheless, the assimilation of radar data over Sardinia added water vapor to the forecast that was advected towards Sicily, enhancing and sustaining the convection triggered by lightning.

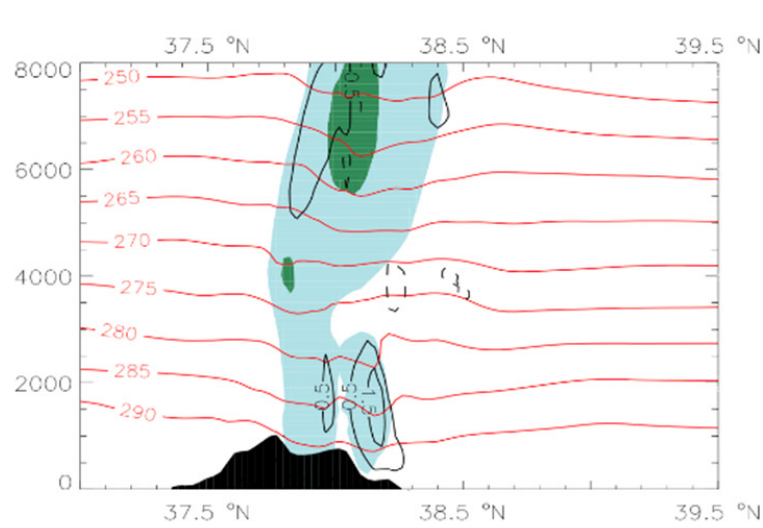

(a)

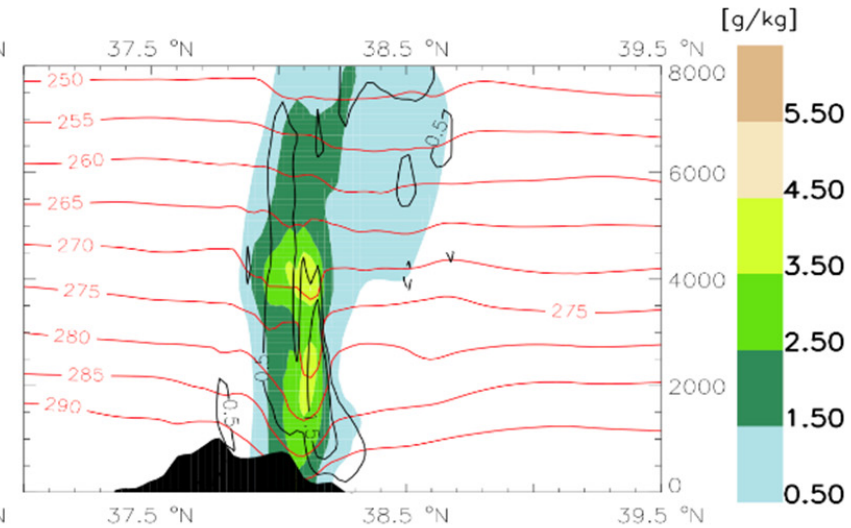

(b)

Figure 11. As in Figure 10 for: (a) LIGHT; (b) RL. Both panels are at 16:00 UTC.

\subsection{Event Predictability}

In this section, we discuss the predictability of this event by analyzing the output of three numerical experiments (Table 3): the first experiment assimilates the lightning and radar reflectivity factor from 06:00 UTC on 15 July 2020 to 13:30 UTC (15:30 LST) on the same day every half hour (experiment RL7.5h); the second experiment assimilates radar reflectivity and lightning every 30 min until 13:00 UTC (15:00 LST; experiment RL7.0h) and the third experiment assimilates lightning and radar reflectivity factor every $30 \mathrm{~min}$ until 12:30 UTC (14:30 LST; experiment RL6.5h). At the time requested, in the current operational set-up of RAMS@ISAC, from the data acquisition to the final forecast, is half an hour, these forecasts would have been available at 14:00 UTC (RL7.5h), 13:30 UTC (RL7.0h) and 13:00 UTC (RL6.5h), before the most intense phase of the storm (15:00-16:00 UTC). To better understand the framework of the simulations presented in this section, we recall that: (a) few millimeters of precipitation were accumulated over some areas of Palermo between 13:00 UTC and 14:00 UTC $(<10 \mathrm{~mm} / \mathrm{h})$; (b) the forecast assimilating lightning and radar reflectivity is available $30 \mathrm{~min}$ from the last analysis time; (c) the RL forecast of the previous section would have been available at 14:30 UTC, when moderate to intense precipitation was already occurring over Palermo.

The precipitation forecast for RL7.5h (Figure 12a) shows more than $60 \mathrm{~mm} / 3 \mathrm{~h}$ for Palermo, with a decrease of about $25 \mathrm{~mm} / 3 \mathrm{~h}$ compared to the RL forecast (Figure 9d). While $60 \mathrm{~mm} / 3 \mathrm{~h}$ is about half of the rainfall recorded in Palermo, this simulation gives a warning for a moderate/intense thunderstorm occurring over the city between 14:00 and 17:00 UTC. The precipitation spell over the sea, west of Sicily, is also reduced; nevertheless, the occurrence of an intense thunderstorm is well predicted in the area. The precipitation spell over eastern Sicily is overestimated by RL7.5h, while the rainfall over Madonie is quite well predicted.

The forecast RL7.0h (Figure 12b) still predicts rainfall between 60 and $70 \mathrm{~mm} / 3 \mathrm{~h}$ over Palermo and gives a warning for a moderate/intense thunderstorm over the city between 14:00 and 17:00 UTC. It is noticed that this maximum tends to shift to the east, compared to RL7.5h and RL, although the spatial error (less than $10 \mathrm{~km}$ from the city center) is small. The precipitation over eastern Sicily is overestimated and lightning and radar reflectivity data assimilation is not able to correct this false alarm. 
a

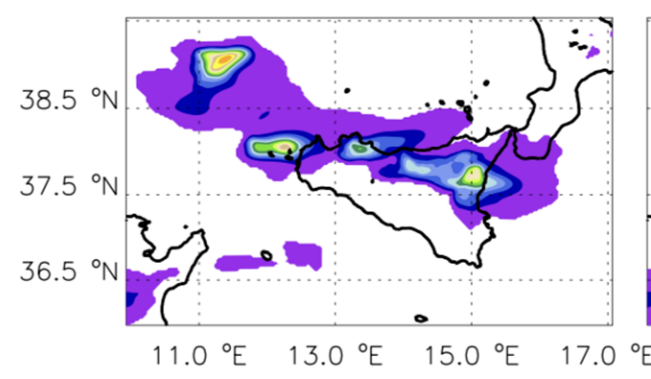

b

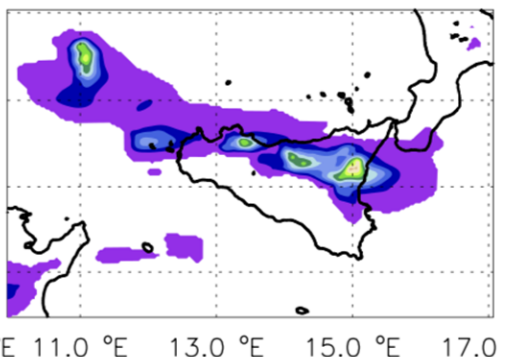

C

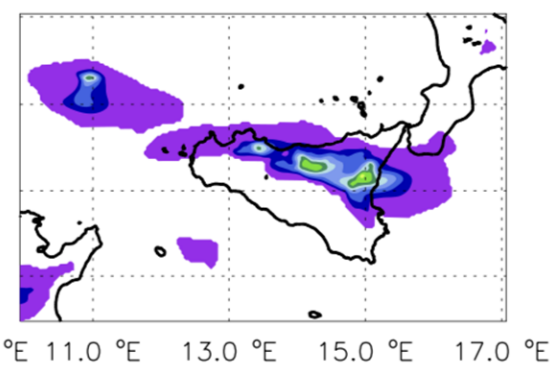

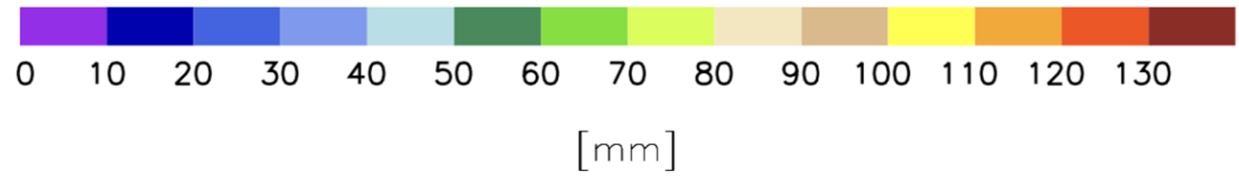

Figure 12. Rainfall forecast between 14:00 and 17:00 UTC on 15 July 2020 for simulations: (a) RL7.5h, (b) RL7.0h, (c) RL6.5h.

The forecast RL6.5h (Figure 12c; the assimilation phase ends at 12:30 UTC, and the forecast is available at 13:00 UTC, i.e., before the precipitation started over Palermo) predicts precipitation between 50 and $60 \mathrm{~mm} / 3 \mathrm{~h}$ close to Palermo, giving the hint of a moderate/intense thunderstorm over the city between 14:00 and 17:00 UTC. The rainfall over Madonie is overestimated, as well as that over eastern Sicily, showing a limited performance of the precipitation forecast compared to the other simulations considered in this section.

Finally, the forecast ending its assimilation phase at 12:00 UTC (not shown) predicts less than $30 \mathrm{~mm} / 3 \mathrm{~h}$ between 14:00 UTC and 17:00 UTC over Palermo, considerably underestimating the event.

In summary, the results of this section show that the assimilation of radar and lightning could give the forecast of a moderate/intense thunderstorm over Palermo about $2 \mathrm{~h}$ before the occurrence of the most intense precipitation phase over the city. Nevertheless, the precision of the forecast, both for the amount of precipitation and for the position, decreases as the forecasting time increases from the end of the assimilation phase.

\section{Conclusions}

The Palermo case occurred on 15 July 2020 between 14:00 UTC and 17:00 UTC. The accumulated rainfall was about $120 \mathrm{~mm} / 3 \mathrm{~h}$ in an urban environment characterized by poor water drainage. Damage to goods was reported in several places. The day before, the forecast correctly issued an alert for eastern Sicily but missed the event in Palermo. The case study can be classified as a deep convective summer event occurring in favorable synopticscale conditions. To improve the forecast of this event, we analyzed the impact of lightning and radar reflectivity data assimilation on the precipitation forecast at a short range.

The lightning data assimilation predicted $55 \mathrm{~mm} / 3 \mathrm{~h}$ over Palermo, which is about half of the observed precipitation, and has a significant impact for this case study for the following three reasons: (a) it corrected the background forecast, whose rainfall prediction over Palermo was negligible; (b) the position of the precipitation spot over Palermo was precisely forecasted when lightning was assimilated; (c) the $55 \mathrm{~mm} / 3 \mathrm{~h}$ showed a moderateintense precipitation with possible impacts in an urban environment.

Although the radar observations over Sicily were not available for this case study, and the radar data assimilation (RDA) alone did not influence the rainfall forecast over Palermo, the RDA had an important impact on the precipitation forecast over the city when used with lightning data assimilation (LDA). In fact, the assimilation of the reflectivity of the Mnt. Armidda radar increased the amount of water vapor between Sicily and Sardinia. This addition of water vapor reinforced and sustained the convection triggered by LDA, 
increasing the rainfall forecast over Palermo from $55 \mathrm{~mm} / 3 \mathrm{~h}$, when only LDA was applied, to $90 \mathrm{~mm} / 3 \mathrm{~h}$, when both LDA and RDA were applied.

The Palermo case is a deep convective event localized in both space and time and the predictability of this type of event is difficult. In this study, we investigated the predictability of the event with a series of simulations, assimilating both radar and lightning data, every $30 \mathrm{~min}$, until 13:30 UTC, 13:00 UTC and 12:30 UTC. The forecasts of these experiments would have been available, with the current operational set-up of RAMS@ISAC, at 14:00 UTC, 13:30 UTC and 13:00 UTC, respectively, before the occurrence of the event over the city or, for the forecast issued at 14:00 UTC, after the event had already started over the city with light rainfall. All these forecasts predict a moderate-intense precipitation over the city $(55-65 \mathrm{~mm} / 3 \mathrm{~h})$. An alert for a moderate-intense precipitation could have been issued before the occurrence of the event or during its early stages, leaving time for possible actions to reduce damage.

While the forecasts presented in this paper could have been useful for the management of the event, the results demonstrate the need to further refine the possible operational forecasting tools, for example, through rapidly updating forecast cycles ( $30 \mathrm{~min}-1 \mathrm{~h}$ ) with data assimilation at the local scale, to better manage deep convective summer events over Italy.

Author Contributions: Conceptualization, S.F., R.C.T., G.V., S.P. and S.D.; methodology, S.F., R.C.T. and E.A.; software, S.F., R.C.T. and E.A.; validation, S.F., R.C.T. and A.C.P.; data curation, S.P. and G.V.; writing —original draft preparation, S.F., R.C.T., E.A. and G.V.; writing—review and editing all authors; supervision, S.D., funding acquisition, S.D. All authors have read and agreed to the published version of the manuscript.

Funding: This research was partially funded by the agreement between the Italian Department of Civil Protection and ISAC-CNR.

Institutional Review Board Statement: Not applicable.

Informed Consent Statement: Not applicable.

Data Availability Statement: Rain gauge data and CAPPIs of radar reflectivity can be requested from the Department of Civil Protection (S.P. and G.V.); RAMS@ISAC output can be requested from S.F.; LINET data can be requested from Nowcast GmbH (https: / / www.nowcast.de/, accessed on 22 July 2021).

Acknowledgments: The computational resources were provided by the European Centre for MediumRange Weather Forecast (ECMWF) through the project SPITFEDE. LINET data were provided by Nowcast GmbH (https: / /www.nowcast.de/, accessed on 22 July 2021)) within a scientific agreement between H.D. Betz and the Satellite Meteorological Group of CNR-ISAC in Rome.

Conflicts of Interest: The authors declare no conflict of interest.

\section{References}

1. Stensrud, D.J.; Xue, M.; Wicker, L.J.; Kelleher, K.E.; Foster, M.P.; Schaefer, J.T.; Schneider, R.S.; Benjamin, S.G.; Weygandt, S.S.; Ferree, J.T.; et al. Convective-scale Warn-On-Forecast system: A vision for 2020. Bull. Am. Meteor. Soc. 2009, 90, 1487-1499. [CrossRef]

2. Fritsch, J.M.; Houze, R.A., Jr.; Adler, R.; Bluestein, H.; Bosart, L.; Brown, J.; Zrnic, D. Quantitative precipitation forecasting: Report of the eighth prospectus development team, U.S. Weather Research Program. Bull. Am. Meteorol. Soc. 1998, 79, 285-299.

3. Sun, J.; Xue, M.; Wilson, J.W.; Zawadzki, I.; Ballard, S.P.; Onvlee-Hooimeyer, J.; Joe, P.; Barker, D.M.; Li, P.-W.; Golding, B.; et al. Use of NWP for Nowcasting Convective Precipitation: Recent Progress and Challenges. Bull. Am. Meteorol. Soc. 2014, 95, 409-426. [CrossRef]

4. Llasat, M.C.; Llasat-Botija, M.; Petrucci, O.; Pasqua, A.A.; Rossello, J.L.; Vinet, F.; Boissier, L. Towards a database on societal impact of Mediterranean floods within the framework of the HYMEX project. Nat. Hazards Earth Syst. Sci. 2013, 13, 1337-1350. [CrossRef]

5. Lee, K.-O.; Flamant, C.; Ducrocq, V.; Duffourg, F.; Fourrié, N.; Davolio, S. Convective initiation and maintenance processes of two back-building mesoscale convective systems leading to heavy precipitation events in Southern Italyduring HyMeX IOP 13. Q. J. R. Meteorol. Soc. 2016, 142, 2623-2635. [CrossRef] 
6. Cassola, F.; Ferrari, F.; Mazzino, A. Numerical simulations of Mediterranean heavy precipitation events with the WRF model: A verification exercise using different approaches. Atmos. Res. 2015, 164-165, 210-225. [CrossRef]

7. Fiori, E.; Ferraris, L.; Molini, L.; Siccardi, F.; Kranzlmueller, D.; Parodi, A. Triggering and evolution of a deep convective system in the Mediterranean Sea: Modelling and observations at a very fine scale. Quart. J. Roy. Meteor. Soc. 2017, 143, 927-941. [CrossRef]

8. Parodi, A.; Kranzlmüller, D.; Clematis, A.; Danovaro, E.; Galizia, A.; Garrote, L.; D'Agostino, D. DRIHM (2US): An e-science environment for hydrometeorological research on high-impact weather events. Bull. Amer. Meteor. Soc. 2017, 98, 2149-2166. [CrossRef]

9. Mazzarella, V.; Ferretti, R.; Picciotti, E.; Marzano, F.S. Investigating 3D and 4D Variational Rapid-Update-Cycling Assimilation of Weather Radar Reflectivity for a Flash Flood Event in Central Italy. Nat. Hazards Earth Syst. Sci. Discuss 2021, 1-26, in review. [CrossRef]

10. Caumont, O.; Mandement, M.; Bouttier, F.; Eeckman, J.; Lebeaupin Brossier, C.; Lovat, A.; Nuissier, O.; Laurantin, O. The heavy precipitation event of 14-15 October 2018 in the Aude catchment: A meteorological study based on operational numerical weather prediction systems and standard and personal observations. Nat. Hazards Earth Syst. Sci. 2021, 21, 1135-1157. [CrossRef]

11. Avolio, E.; Federico, S. WRF simulations for a heavy rainfall event in southern Italy: Verification and sensitivity tests. Atmos. Res. 2018, 209, 14-35. [CrossRef]

12. Torcasio, R.C.; Federico, S.; Puca, S.; Vulpiani, G.; Prat, A.C.; Dietrich, S. Application of Lightning Data Assimilation for the 10 October 2018 Case Study over Sardinia. Atmosphere 2020, 11, 541. [CrossRef]

13. Jansa, A.; Alpert, P.; Arbogast, P.; Buzzi, A.; Ivancanpicek, B.; Kotroni, V.; Llasat, M.C.; Ramis, C.; Richard, E.; Romero, R.; et al. MEDEX: A general overview. Nat. Hazards Earth Syst. Sci. 2014, 14, 1965-1984. [CrossRef]

14. Flaounas, E.; Raveh-Rubin, S.; Wernli, H.; Drobinski, P.; Bastin, S. The dynamical structure of intense Mediterranean cyclones. Clim. Dyn. 2015, 44, 2411. [CrossRef]

15. Flaounas, E.; Lagouvardos, K.; Kotroni, V.; Claud, C.; Delanoë, J.; Flamant, C.; Madonna, E.; Wernli, H. Processes leading to heavy precipitation associated with two mediterranean cyclones observed during the HyMeX SOP1. Q. J. R. Meteorol. Soc. 2016, 142, 275-286. [CrossRef]

16. Laviola, S.; Moscatello, A.; Miglietta, M.M.; Levizzani, V. Satellite and numerical model investigation of two mesoscal econvective systems over Central Mediterranean. J. Hydrometeorol. 2011, 12, 634-649. [CrossRef]

17. Houze, R.A., Jr. Mesoscale convective systems. Rev. Geophys. 2004, 42, RG4003. [CrossRef]

18. Ricard, D.; Ducrocq, V.; Auger, L. A climatology of mesoscale environment asso- ciated with Mediterranean heavy precipitating events over a Northwestern Mediterranean area. J. Appl. Meteorol. Climatol. 2012, 51, 468-488. [CrossRef]

19. Gascòn, E.; Laviola, S.; Merino, A.; Miglietta, M.M. Analysis of a localized flash- flood event over the central Mediterranean. Atmos. Res. 2016, 182, 256-268. [CrossRef]

20. Chiaravalloti, F.; Gabriele, S. Vibo Valentia flood and MSG rainfall evaluation. Atmos. Res. 2009, 93, 286-294. [CrossRef]

21. Federico, S.; Bellecci, C.; Colacino, M. Quantitative precipitation of the Soverato flood: The role of orography and surface fluxes. II Nuovo Cimento C 2003, 26, 7-22.

22. Federico, S.; Avolio, E.; Pasqualoni, L.; Bellecci, C. Atmospheric patterns for heavy rain events in Calabria. Nat. Hazards Earth Syst. Sci. 2008, 8, 1173-1186. [CrossRef]

23. Greco, A.; De Luca, D.L.; Avolio, E. Heavy Precipitation Systems in Calabria Region (Southern Italy): High-Resolution Observed Rainfall and Large-Scale Atmospheric Pattern Analysis. Water 2020, 12, 1468. [CrossRef]

24. Ducrocq, V.; Braud, I.; Davolio, S.; Ferretti, R.; Flamant, C.; Jansá, A.; Kalthoff, N.; Richard, E.; Taupier-Letage, I.; Ayral, P.-A.; et al. HyMeX-SOP1: The Field Campaign Dedicated to Heavy Precipitation and Flash Flooding in the Northwestern Mediterranean. Bull. Am. Meteorol. Soc. 2014, 95, 1083-1100. [CrossRef]

25. Ferretti, R.; Pichelli, E.; Gentile, S.; Maiello, I.; Cimini, D.; Davolio, S.; Miglietta, M.M.; Panegrossi, G.; Baldini, L.; Pasi, F.; et al. Overview of the first HyMeX Special Observation Period over Italy: Observations and model results. Hydrol. Earth Syst. Sci. 2014, 18, 1953-1977. [CrossRef]

26. Sun, J.; Wang, H. Radar Data Assimilation with WRF 4D-Var. Part II: Comparison with 3D-Var for a Squall Line over the U.S. Great Plains. Mon. Weather Rev. 2013, 141, 2245-2264. [CrossRef]

27. Wang, H.; Sun, J.; Fan, S.; Huang, X. Indirect Assimilation of Radar Reflectivity with WRF 3D-Var and Its Impact on Prediction of Four Summertime Convective Events. J. Appl. Meteor. Climatol. 2013, 52, 889-902. [CrossRef]

28. Lagasio, M.; Silvestro, F.; Campo, L.; Parodi, A. Predictive Capability of a High-Resolution Hydrometeorological Forecasting Framework Coupling WRF Cycling 3DVAR and Continuum. J. Hydrometeor. 2019, 20, 1307-1337. [CrossRef]

29. Benjamin, S.G.; Dévényi, D.; Weygandt, S.S.; Brundage, K.J.; Brown, J.M.; Grell, G.A.; Manikin, G.S. An Hourly AssimilationForecast Cycle: The RUC. Mon Weather Rev. 2004, 132, 495-518. [CrossRef]

30. Alexander, G.D.; Weinman, J.A.; Karyampudi, V.M.; Olson, W.S.; Lee, A.C.L. The Effect of Assimilating Rain Rates Derived from Satellites and Lightning on Forecasts of the 1993 Superstorm. Mon. Weather Rev. 1999, 127, 1433-1457. [CrossRef]

31. Chang, D.-E.; Weinman, J.A.; Morales, C.A.; Olson, W.S. The Effect of Spaceborne Microwave and Ground-Based Continuous Lightning Measurements on Forecasts of the 1998 Groundhog Day Storm. Mon. Weather Rev. 2001, 129, 1809-1833. [CrossRef]

32. Jones, C.D.; MacPherson, B. A latent heat nudging scheme for the assimilation of precipitation data into an operational mesoscale model. Meteorol. Appl. 1997, 4, 269-277. [CrossRef] 
33. Pessi, A.T.; Businger, S. Relationships among Lightning, Precipitation, and Hydrometeor Characteristics over the North Pacific Ocean. J. Appl. Meteorol. Clim. 2009, 48, 833-848. [CrossRef]

34. Papadopoulos, A.; Chronis, T.G.; Anagnostou, E.N. Improving Convective Precipitation Forecasting through Assimilation of Regional Lightning Measurements in a Mesoscale Model. Mon. Weather Rev. 2005, 133, 1961-1977. [CrossRef]

35. Mansell, E.R.; Ziegler, C.L.; MacGorman, D.R. A Lightning Data Assimilation Technique for Mesoscale Forecast Models. Mon. Weather Rev. 2007, 135, 1732-1748. [CrossRef]

36. Lagouvardos, K.; Kotroni, V.; Defer, E.; Bousquet, O. Study of a heavy precipitation event over southern France, in the frame of HYMEX project: Observational analysis and model results using assimilation of lightning. Atmos. Res. 2013, 134, 45-55. [CrossRef]

37. Giannaros, T.M.; Kotroni, V.; Lagouvardos, K. WRF-LTNGDA: A lightning data assimilation technique implemented in the WRF model for improving precipitation forecasts. Environ. Model. Softw. 2016, 76, 54-68. [CrossRef]

38. Wang, H.; Chen, D.; Yin, J.; Xu, D.; Dai, G.; Chen, L. An improvement of convective precipitation nowcasting through lightning data dynamic nudging in a cloud-resolving scale forecasting system. Atmos. Res. 2020, 242, 104994. [CrossRef]

39. Gan, R.; Yang, Y.; Qiu, X.; Wang, R.; Qiu, X.; Zhu, L. Assimilation of the Maximum Vertical Velocity Converted from Total Lightning Data through the EnSRF Method. J. Geophys. Res. Atmos. 2021, 126, e2020JD034300. [CrossRef]

40. Williams, E.R. Large-scale charge separation in thunderclouds. J. Geophys. Res. Space Phys. 1985, 90, 6013. [CrossRef]

41. Price, C.; Rind, D. A simple lightning parameterization for calculating global lightning distributions. J. Geophys. Res. Space Phys. 1992, 97, 9919-9933. [CrossRef]

42. Marchand, M.; Fuelberg, H. Assimilation of lightning data using a nudging method involving low-level warming. Mon. Weather Rev. 2014, 142, 4850-4871. [CrossRef]

43. Fierro, A.; Mansell, E.R.; Ziegler, C.L.; MacGorman, D.R. Application of a Lightning Data Assimilation Technique in the WRFARW Model at Cloud-Resolving Scales for the Tornado Outbreak of 24 May 2011. Mon. Weather Rev. 2012, 140, $2609-2627$. [CrossRef]

44. Fierro, A.; Gao, J.; Ziegler, C.L.; Mansell, E.R.; MacGorman, D.R.; Dembek, S.R. Evaluation of a Cloud-Scale Lightning Data Assimilation Technique and a 3DVAR Method for the Analysis and Short-Term Forecast of the 29 June 2012 Derecho Event. Mon. Weather Rev. 2014, 142, 183-202. [CrossRef]

45. Fierro, A.O.; Gao, J.; Ziegler, C.L.; Calhoun, K.M.; Mansell, E.R.; MacGorman, D.R. Assimilation of Flash Extent Data in the Variational Framework at Convection-Allowing Scales: Proof-of-Concept and Evaluation for the Short-Term Forecast of the 24 May 2011 Tornado Outbreak. Mon. Weather Rev. 2016, 144, 4373-4393. [CrossRef]

46. Fierro, A.O.; Wang, Y.; Gao, J.; Mansell, E.R. Variational Assimilation of Radar Data and GLM Lightning-Derived Water Vapor for the Short-Term Forecasts of High-Impact Convective Events. Mon. Weather Rev. 2019, 147, 4045-4069. [CrossRef]

47. Wang, Y.; Yang, Y.; Liu, D.; Zhang, D.; Yao, W.; Wang, C. A Case Study of Assimilating Lightning-Proxy Relative Humidity with WRF-3DVAR. Atmosphere 2017, 8, 55. [CrossRef]

48. Hu, J.; Fierro, A.O.; Wang, Y.; Gao, J.; Mansell, E.R. Exploring the Assimilation of GLM Derived Water Vapor Mass in a Cycled 3DVAR Framework for the Short-term Forecasts of High Impact Convective Events. Mon. Wea. Rev. 2019. [CrossRef]

49. Liu, P.; Yang, Y.; Gao, J.; Wang, Y.; Wang, C. An Approach for Assimilating FY4 Lightning and Cloud Top Height Data Using 3DVAR. Front. Earth Sci. 2020, 8, 288. [CrossRef]

50. Gan, R.; Yang, Y.; Xie, Q.; Lin, E.; Wang, Y.; Liu, P. Assimilation of radar and cloud-to-ground lightning data using WRF-3DVar combined with the physical initialization method A case study of a mesoscale convective system. J. Meteor. Res. 2020, 35, 329-342. [CrossRef]

51. Federico, S.; Petracca, M.; Panegrossi, G.; Dietrich, S. Improvement of RAMS precipitation forecast at the short-range through lightning data assimilation. Nat. Hazards Earth Syst. Sci. 2017, 17, 61-76. [CrossRef]

52. Federico, S.; Torcasio, R.C.; Avolio, E.; Caumont, O.; Montopoli, M.; Baldini, L.; Vulpiani, G.; Dietrich, S. The impact of lightning and radar reflectivity factor data assimilation on the very short-term rainfall forecasts of RAMS@ISAC: Application to two case studies in Italy. Nat. Hazards Earth Syst. Sci. 2019, 19, 1839-1864. [CrossRef]

53. Comellas Prat, A.; Federico, S.; Torcasio, R.C.; Fierro, A.O.; Dietrich, S. Lightning data assimilation in the WRF-ARW model for short- term rainfall forecasts of three severe storm cases in Italy. Atmos. Res. 2021, 247, 105246. [CrossRef]

54. Torcasio, R.C.; Federico, S.; Comellas Prat, A.; Panegrossi, G.; D’Adderio, L.P.; Dietrich, S. Impact of Lightning Data Assimilation on the Short-Term Precipitation Forecast over Central Mediterranean Sea. Remote Sens. 2021, 13, 682. [CrossRef]

55. Xiao, Q.; Sun, J. Multiple-radar data assimilation and short-range quantitative precipitation forecasting of a squall line observed during IHOP_2002. Mon. Weather Rev. 2007, 135, 3381-3404. [CrossRef]

56. Lee, J.-H.; Lee, H.-H.; Choi, Y.; Kim, H.-W.; Lee, D.-K. Radar data assimilation for the simulation of mesoscale convective systems. Adv. Atmos. Sci. 2010, 27, 1025-1042. [CrossRef]

57. Lee, J.-W.; Min, K.-H.; Lee, Y.-H.; Lee, G. X-Net-Based Radar Data Assimilation Study over the Seoul Metropolitan Area. Remote Sens. 2020, 12, 893. [CrossRef]

58. Ha, J.; Kim, H.; Lee, D. Observation and numerical simulations with radar and surface data assimilation for heavy rainfall over central Korea. Adv. Atmos. Sci. 2011, 28, 573-590. [CrossRef]

59. Wang, H.; Huang, X.Y.; Sun, J. A comparison between the 3/4DVAR and hybrid ensemble-VAR techniques for radar data assimilation. In Proceedings of the 35th Conference on Radar Meteorology, Breckenridge, CO, USA, 16-20 September 2013. 
60. Gastaldo, T.; Poli, V.; Marsigli, C.; Alberoni, P.P.; Paccagnella, T. Data assimilation of radar reflectivity volumes in a LETKF scheme. Nonlin. Processes Geophys. 2018, 25, 747-764. [CrossRef]

61. Maiello, I.; Gentile, S.; Ferretti, R.; Baldini, L.; Roberto, N.; Picciotti, E.; Alberoni, P.P.; Marzano, F.S. Impact of multiple radar reflectivity data assimilation on the numerical simulation of a flash flood event during the HyMeX campaign. Hydrol. Earth Syst. Sci. 2017, 21, 5459-5476. [CrossRef]

62. Mazzarella, V.; Maiello, I.; Capozzi, V.; Budillon, G.; Ferretti, R. Comparison between 3D-Var and 4D-Var data assimilation methods for the simulation of a heavy rainfall case in central Italy. Adv. Sci. Res. 2017, 14, 271-278. [CrossRef]

63. Cotton, W.R.; Sr, R.A.P.; Walko, R.L.; Liston, G.E.; Tremback, C.J.; Jiang, H.; McAnelly, R.L.; Harrington, J.Y.; Nicholls, M.E.; Carrio, G.G.; et al. RAMS 2001: Current status and future directions. Theor. Appl. Clim. 2003, 82, 5-29. [CrossRef]

64. Hong, S.Y.; Lim, J.J.O. The WRF single-moment 6-class microphysics scheme (WSM6). J. Korean Meteorol. Soc. 2006, 42, 129-151.

65. Federico, S. Implementation of the WSM5 and WSM6 Single Moment Microphysics Scheme into the RAMS Model: Verification for the HyMeX-SOP1. Adv. Meteorol. 2016, 2016, 1-17. [CrossRef]

66. Dahl, J.M.L.; Höller, H.; Schumann, U. Modeling the Flash Rate of Thunderstorms. Part II: Implementation. Mon. Weather Rev. 2011, 139, 3112-3124. [CrossRef]

67. Federico, S.; Avolio, E.; Petracca, M.; Panegrossi, G.; Sanò, P.; Casella, D.; Dietrich, S. Simulating lightning into the RAMS model: Implementation and preliminary results. Nat. Hazards Earth Syst. Sci. 2014, 14, 2933-2950. [CrossRef]

68. Federico, S. Implementation of a 3D-Var system for atmospheric profiling data assimilation into the RAMS model: Initial results. Atmos. Meas. Tech. 2013, 6, 3563-3576. [CrossRef]

69. Mascitelli, A.; Federico, S.; Torcasio, R.C.; Dietrich, S. Assimilation of GPS Zenith Total Delay estimates in RAMS NWP model: Impact studies over central Italy, Adv. Space Res. 2020, in press. [CrossRef]

70. Walko, R.L.; Band, L.E.; Baron, J.; Kittel, T.G.; Lammers, R.; Lee, T.J.; Ojima, D.; Pielke Sr, R.A.; Taylor, C.; Tague, C.; et al. Coupled Atmosphere-Biosphere-Hydrology Models for environmental prediction. J. Appl. Meteorol. 2000, 39, 931-944. [CrossRef]

71. Smagorinsky, J. General circulation experiments with the primitive equations. Part I, The basic experiment. Mon. Weather Rev. 1963, 91, 99-164. [CrossRef]

72. Mellor, G.L.; Yamada, T. Development of a turbulence closure model for geophysical fluid problems. Rev. Geophys. 1982, $20,851$. [CrossRef]

73. Chen, C.; Cotton, W.R. A one-dimensional simulation of the stratocumulus-capped mixed layer. Bound. Layer Meteorol. 1983, 25, 289-321. [CrossRef]

74. Betz, H.D.; Schmidt, K.; Laroche, P.; Blanchet, P.; Oettinger, W.P.; Defer, E.; Dziewit, Z.; Konarski, J. LINET—An international lightning detection network in Europe. Atmos. Res. 2009, 91, 564-573. [CrossRef]

75. Betz, H.-D.; Schmidt, K.; Oettinger, P.; Wirz, M. Lightning detection with 3D-discrimination of intracloud and cloud-to-ground discharges. J. Geophys. Res. Lett. 2004, 31, L11108. [CrossRef]

76. Vulpiani, G.; Rinollo, A.; Puca, S.; Montopoli, M. A Quality-Based Approach for Radar Rain Field Reconstruction and the H-Saf Precipitation Products Validation. In Proceedings of the Eighth European Radar Conference Garmish-Partenkirchen, Germany, ERAD, Garmisch-Partenkirchen, Germany, 1-5 September 2014; Volume 220, p. 6. Available online: http:/ / www.pa.op.dlr.de/ erad2014/programme/ExtendedAbstracts/220_Vulpiani.pdf (accessed on 4 May 2021).

77. Petracca, M.; D'Adderio, L.P.; Porcù, F.; Vulpiani, G.; Sebastianelli, S.; Puca, S. Validation of GPM Dual-Frequency Precipitation Radar (DPR) rainfall products over Italy. J. Hydrometeorol. 2018, 19, 907-925. [CrossRef]

78. Caumont, O.; Ducrocq, V.; Wattrelot, E.; Jaubert, G.; Pradier-Vabre, S. 1D+3DVar assimilation of radar reflectivity data: A proof of concept. Tellus A. 2010, 62, 173-187. [CrossRef]

79. Olson, W.S.; Kummerow, C.D.; Heymsfield, G.M.; Giglio, L. A method for combined passive-active microwave retrievals of cloud and precipitation profiles. J. Appl. Meteorol. 1996, 35, 17631789. [CrossRef]

80. Kummerow, C.; Hong, Y.; Olson, W.S.; Yang, S.; Adler, R.F.; McCollum, J.; Ferraro, R.; Petty, G.; Shin, D.-B.; Wilheit, T.T. The evolution of the Goddard profiling algorithm (GPROF) for rainfall estimation from passive microwave sensors. J. Appl. Meteorol. 2001, 40, 1801-1820. [CrossRef]

81. Parrish, D.F.; Derber, J.C. The National Meteorological Center's Spectral Statistical Interpolation analysis system. Mon. Weather Rev. 1992, 120, 1747-1763. [CrossRef]

82. Barker, D.M.; Huang, X.-Y.; Liu, Z.; Aulignè, T.; Zhang, X.; Rugg, S.; Ajjaji, R.; Bourgeois, A.; Bray, J.; Chen, Y.; et al. The Weather Research and Forecasting (WRF) Model's Community Variational/Ensemble Data Assimilation System: WRFDA. B. Am. Meteorol. Soc. 2012, 93, 831-843. [CrossRef]

83. Huffman, G.J.; Stocker, E.F.; Bolvin, D.T.; Nelkin, E.J.; Tan, J. GPM IMERG Final Precipitation L3 Half Hourly 0.1 degree $\times 0.1$ degree V06, Greenbelt, MD, Goddard Earth Sciences Data and Information Services Center (GES DISC). 2019. Available online: https: / / www.doi.org/10.5067/GPM/IMERG/3B-HH/06 (accessed on 4 May 2021). 